\title{
Lietuvos vokiečių ir lietuvių santykiai Evangelikų Liuteronų Bažnyčioje 1918-1940 m.
}

\begin{abstract}
Straipsnyje, remiantis gausia archyvine medžiaga, nagrinëjami Lietuvos vokiečių ir lietuvių santykiai Evangelikų Liuteronų Bažnyčioje 1918-1940 m.: atskleidžiamas šių evangelikų grupių statistinis pasiskirstymas šalyje, abiejų religinių grupių požiūris ị Lietuvos evangelikų liuteronų konsistoriją, siekiai igyti didesnę ịtaką evangelikų liuteronų bendruomeneje ar net jai net vadovauti.

Based on abundant archival data the article addresses the relations between Lithuanian Germans and Lithuanians in the Evangelical Lutheran Church in 1918-1940: it reveals the statistical distribution of these evangelical groups in the country, the approach of the two religious groups towards the Consistory of Lithuanian Evangelical Lutherans, and their aspirations to gain the greatest possible influence over the Evangelical Lutheran community or even lead it.
\end{abstract}

\section{Ivadas}

Lietuvos vokiečiu ir lietuvių santykiai Evangelikų Liuteronų Bažnyčioje istoriografų išsamiai netyrinèti. Išimtis - vokiečių istoriko Arthuro Hermanno tyrimai ${ }^{1}$, kuriuose bendrais bruožais apžvelgiama ir Lietuvos evangelikų liuteronų konsistorijos, vokiečių tautybės evangelikų liuteronų veikla, jų santykiai su lietuvių tautybės evangelikais liuteronais ir kiti panašūs klausimai. Istorikè Marija Gražina Slavėnienè nagrinėjo Evangelikų teologijos fakulteto veiklą Kaune 1925-1936 m. ${ }^{2}$. Inga Puidokiené magistro darbe (jame bendrais bruožais pristatoma vokiečių tautinè mažuma Lietuvoje 1918-1940 m. [be Klaipèdos krašto]) $)^{3}$, o ypač dviejuose moksliniuose straipsniuose ${ }^{4}$, remdamasi jau minèto A. Hermano paskelbtais darbais ir gana gausia archyvine medžiaga, daugiausia dèmesio skyrẻ Kauno Evangelikų Liuteronų Bažnyčios vidaus konfliktui 1918-1940 m. ir apskritai Kauno evangelikų liuteronų parapijai 1919-1953 m. Kadangi minèti darbai neleidžia susidaryti išsamaus vaizdo apie Lietuvos vokiečiu ir lietuvių santykius Evangelikų Liuteronų Bažnyčioje aptariamuoju laikotarpiu, siekiant užpildyti istoriografijos baltuosius puslapius ir nutarta paskelbti šią publikaciją.

Straipsnio tikslas - ištirti Lietuvos vokiečių ir lietuvių santykius Evangelikų Liuteronų Bažnyčioje 1918-1940 metais. Tikslui pasiekti keliami šie uždaviniai: a) paaiškinti vokiečių vyravimo Lietuvos evangelikų liuteronų bendruomenèje pirmajame nepriklausomybès dešimtmetyje priežastis; b) išanalizuoti, kodèl Lietuvos evangelikų liuteronų bendruomeneje XX a. 4-ajame dešimtmetyje vokiečiai prarado vadovaujamąsias pozicijas. 
Pasirinktą temą padejjo atskleisti gausi archyvinė medžiaga, kurios didžioji dalis saugoma Lietuvos centriniame valstybės archyve (LCVA). Itin vertinga LCVA, Valstybès saugumo departamento fonde (f. 378), esanti medžiaga (mėnesių apžvalgos ir politinès policijos parengti, sudaryti biuleteniai) apie Lietuvoje gyvenusių vokiečių veiklą. Remtasi Vidaus reikalų ministerijos (f. 377), atskirų Lietuvos miestų savivaldybių ir kituose LCVA fonduose saugomais dokumentais, to meto periodine spauda.

\section{Lietuvos evangelikų liuteronų tautinis pasiskirstymas ir lietuvių tautybės evangelikų liuteronų kunigų stoka}

1923 m. visuotinio gyventojų surašymo duomenimis, Lietuvoje vietos vokiečiai (be Klaipeddos krašto), kurių tuo metu gyveno 29 231, pagal religiją buvo pasiskirstę taip: Romos katalikai - 207, judaistai - 1, evangelikai liuteronai - 28671 (tai sudarè net 98,08 proc. visų Lietuvos vokiečių ${ }^{5}$ ), stačiatikiai - 26, evangelikai reformatai - 212, baptistai - 48, evangelikai metodistai - 43, laisvieji evangelikai - 18, netikintieji - 1, adventistai $-4^{6}$. Minètas surašymas parodè, kad Lietuvoje didžiausi evangelikų reformatų centrai buvo Tauragès, Vilkaviškio, Šiaulių, Kauno, Šakių, Marijampolès, Biržų apskritys (žr. 1 ir 2 lenteles). A. Hermanas teigia (remdamasis 1923 m. gyventojų surašymo duomenimis): „Kadangi beveik visi vokiečiai buvo liuteronai, galima manyti, kad būta [evangelikų liuteronų] apie 28 tūkst. vokiečių, apie 22 tūkst. lietuvių ir apie 12 tūkst. latvių [minèto surašymo duomenimis, Lietuvos piliečiai - evangelikai liuteronai - pagal tautybę pasiskirstė taip: vokiečiai - 43,06 proc., lietuviai - 33,51 proc., latviai - 20,36 proc., likusią nedidelę evangelikų liuteronų dalị sudarė kitos tautos ir svetimšaliai ${ }^{7}-$ M. T. pastaba]. Šie skaičiai vèliau kito lietuvių grupès naudai $<\ldots>$, bet trečiajame dešimtmetyje vokiečiai visur dar pirmavo, nes buvo geriau išsilavinę ir užèmè visas svarbesnes vietas bažnyčioje." ${ }^{\text {"8 }}$

1 lentelè. Lietuvos gyventojų konfesinė sudètis $1923 \mathrm{~m}$. rugsẻjo $17 \mathrm{~d}$. apskritimis (Lentelè paimta iš http:// gevask.dtiltas.It/LS1919/HTM/a060.html. Žiūrèta 2013-08-12.)

\begin{tabular}{|l|l|l|l|l|l|l|l|l|l|l|l|}
\hline Apskritis & Iš viso & $\begin{array}{l}\text { Romos } \\
\text { katali- } \\
\text { kai }\end{array}$ & $\begin{array}{l}\text { Judais- } \\
\text { tai }\end{array}$ & $\begin{array}{l}\text { Evan- } \\
\text { geli- } \\
\text { kai } \\
\text { liute- } \\
\text { ronys }\end{array}$ & $\begin{array}{l}\text { Senti- } \\
\text { kiai }\end{array}$ & $\begin{array}{l}\text { Sta- } \\
\text { čiati- } \\
\text { kiai }\end{array}$ & $\begin{array}{l}\text { Evan- } \\
\text { geli- } \\
\text { kai } \\
\text { refor- } \\
\text { matai }\end{array}$ & $\begin{array}{l}\text { Mu- } \\
\text { sul- } \\
\text { mo- } \\
\text { nai }\end{array}$ & $\begin{array}{l}\text { Bap- } \\
\text { tistai }\end{array}$ & $\begin{array}{l}\text { Ka- } \\
\text { rai- } \\
\text { mai }\end{array}$ & $\begin{array}{l}\text { Kiti ir } \\
\text { nenu- } \\
\text { rodyti }\end{array}$ \\
\hline Iš viso & 2028971 & 1739393 & 155125 & 66578 & 32149 & 22925 & 10678 & 1107 & 379 & 155 & 482 \\
\hline Alytaus & 109678 & 99630 & 7798 & 629 & 201 & 672 & 13 & 732 & - & 2 & 1 \\
\hline Biržų & 115186 & 95364 & 4964 & 3799 & 474 & 869 & 9642 & 1 & 15 & 29 & 29 \\
\hline Kauno & 191364 & 142743 & 32035 & 5759 & 5508 & 4329 & 620 & 109 & 78 & 5 & 178 \\
\hline Kèdainių & 86099 & 78436 & 5473 & 407 & 975 & 765 & 35 & 1 & - & 5 & 2 \\
\hline Kretingos & 93875 & 83622 & 5846 & 3913 & 56 & 330 & 8 & - & 80 & - & 20 \\
\hline Marijampolès & 99220 & 87218 & 6554 & 4947 & 26 & 446 & 15 & 2 & 1 & - & 11 \\
\hline Mažeikių & 71104 & 61810 & 4012 & 3504 & 852 & 731 & 2 & - & 183 & - & 10 \\
\hline Panevežio & 138917 & 122467 & 12519 & 534 & 2053 & 1166 & 42 & 1 & 4 & 113 & 18 \\
\hline
\end{tabular}




\begin{tabular}{|l|l|l|l|l|l|l|l|l|l|l|l|}
\hline Apskritis & Iš viso & $\begin{array}{l}\text { Romos } \\
\text { katali- } \\
\text { kai }\end{array}$ & $\begin{array}{l}\text { Judais- } \\
\text { tai }\end{array}$ & $\begin{array}{l}\text { Evan- } \\
\text { geli- } \\
\text { kai } \\
\text { liute- } \\
\text { ronys }\end{array}$ & $\begin{array}{l}\text { Senti- } \\
\text { kiai }\end{array}$ & $\begin{array}{l}\text { Sta- } \\
\text { čiati- } \\
\text { kiai }\end{array}$ & $\begin{array}{l}\text { Evan- } \\
\text { geli- } \\
\text { kai } \\
\text { refor- } \\
\text { matai }\end{array}$ & $\begin{array}{l}\text { Mu- } \\
\text { sul- } \\
\text { mo- } \\
\text { nai }\end{array}$ & $\begin{array}{l}\text { Bap- } \\
\text { tistai }\end{array}$ & $\begin{array}{l}\text { Ka- } \\
\text { rai- } \\
\text { mai }\end{array}$ & $\begin{array}{l}\text { Kiti ir } \\
\text { nenu- } \\
\text { rodyti }\end{array}$ \\
\hline Raseinių & 108024 & 93759 & 8197 & 4206 & 459 & 1317 & 51 & - & - & - & 35 \\
\hline Rokiškio & 83220 & 71905 & 5141 & 670 & 5146 & 348 & 7 & 1 & - & - & 2 \\
\hline Seinų & 38207 & 34814 & 2173 & 489 & 496 & 218 & 9 & 8 & - & - & - \\
\hline Šakių & 67474 & 58583 & 2983 & 5564 & 43 & 163 & 95 & 1 & 7 & - & 35 \\
\hline Šiaulių & 198015 & 172634 & 13573 & 6078 & 2993 & 2579 & 117 & 12 & 6 & - & 23 \\
\hline Tauragès & 110965 & 90345 & 6198 & 13317 & 252 & 838 & 9 & - & - & 1 & 5 \\
\hline Telšių & 80452 & 72026 & 6334 & 289 & 487 & 1272 & - & - & - & - & 44 \\
\hline Trakų & 78636 & 71070 & 4357 & 106 & 802 & 2177 & 1 & 122 & - & - & 1 \\
\hline Utenos & 108960 & 95771 & 8076 & 96 & 3079 & 1920 & 2 & 16 & - & - & - \\
\hline Ukmergès & 126309 & 114451 & 8219 & 125 & 2054 & 1405 & 9 & 44 & - & - & 2 \\
\hline Vilkaviškio & 80609 & 60252 & 7241 & 12073 & 10 & 960 & 1 & 1 & 5 & - & 66 \\
\hline Zarasų & 42657 & 32493 & 3432 & 73 & 6183 & 420 & - & 56 & - & - & - \\
\hline
\end{tabular}

2 lentelè. Lietuvos gyventojų konfesinė sudėtis $1923 \mathrm{~m}$. rugsẻjo $17 \mathrm{~d}$. apskritimis \% (Lentelè paimta iš http://gevask.dtiltas.It/LS1919/HTM/a061.html. Žiürèta 2013-08-12.)

\begin{tabular}{|l|l|l|l|l|l|l|l|l|l|l|l|}
\hline Apskritis & Iš viso & $\begin{array}{l}\text { Romos } \\
\text { katali- } \\
\text { kai }\end{array}$ & $\begin{array}{l}\text { Ju- } \\
\text { dais- } \\
\text { tai }\end{array}$ & $\begin{array}{l}\text { Evan- } \\
\text { gelikai } \\
\text { liute- } \\
\text { ronys }\end{array}$ & $\begin{array}{l}\text { Sen- } \\
\text { tikiai }\end{array}$ & $\begin{array}{l}\text { Stačia- } \\
\text { tikiai }\end{array}$ & $\begin{array}{l}\text { Evan- } \\
\text { gelikai } \\
\text { refor- } \\
\text { matai }\end{array}$ & $\begin{array}{l}\text { Mu- } \\
\text { sul- } \\
\text { monai }\end{array}$ & $\begin{array}{l}\text { Bap- } \\
\text { tistai }\end{array}$ & $\begin{array}{l}\text { Ka- } \\
\text { rai- } \\
\text { mai }\end{array}$ & $\begin{array}{l}\text { Kiti ir } \\
\text { nenu- } \\
\text { rodyti }\end{array}$ \\
\hline Iš viso & 100,00 & 85,73 & 7,65 & 3,28 & 1,58 & 1,13 & 0,53 & 0,05 & 0,02 & 0,01 & 0,02 \\
\hline Alytaus & 100,00 & 90,84 & 7,11 & 0,57 & 0,18 & 0,61 & 0,01 & 0,67 & - & 0,00 & 0,00 \\
\hline Biržų & 100,00 & 82,79 & 4,31 & 3,30 & 0,41 & 0,75 & 8,37 & 0,00 & 0,01 & 0,03 & 0,03 \\
\hline Kauno & 100,00 & 74,59 & 16,74 & 3,01 & 2,88 & 2,26 & 0,32 & 0,06 & 0,04 & 0,00 & 0,09 \\
\hline Kėdainių & 100,00 & 91,10 & 6,36 & 0,47 & 1,13 & 0,89 & 0,04 & 0,00 & - & 0,00 & 0,00 \\
\hline Kretingos & 100,00 & 89,08 & 6,23 & 4,17 & 0,06 & 0,35 & 0,01 & - & 0,09 & - & 0,02 \\
\hline Marijampoless & 100,00 & 87,90 & 6,61 & 4,99 & 0,03 & 0,45 & 0,02 & 0,00 & 0,00 & - & 0,01 \\
\hline Mažeikių & 100,00 & 86,93 & 5,64 & 4,93 & 1,20 & 1,03 & 0,00 & - & 0,26 & - & 0,01 \\
\hline Panevežio & 100,00 & 88,16 & 9,01 & 0,38 & 1,48 & 0,84 & 0,03 & 0,00 & 0,00 & 0,08 & 0,01 \\
\hline Raseinių & 100,00 & 86,79 & 7,59 & 3,89 & 0,42 & 1,22 & 0,05 & - & - & - & 0,03 \\
\hline Rokiškio & 100,00 & 86,40 & 6,18 & 0,81 & 6,18 & 0,42 & 0,01 & 0,00 & - & - & 0,00 \\
\hline Seinų & 100,00 & 91,12 & 5,69 & 1,28 & 1,30 & 0,57 & 0,02 & 0,02 & - & - & - \\
\hline Šakių & 100,00 & 86,82 & 4,42 & 8,25 & 0,06 & 0,24 & 0,14 & 0,00 & 0,01 & - & 0,05 \\
\hline Šiaulių & 100,00 & 87,18 & 6,85 & 3,07 & 1,51 & 1,30 & 0,06 & 0,01 & 0,00 & - & 0,01 \\
\hline Tauragès & 100,00 & 81,42 & 5,59 & 12,00 & 0,23 & 0,76 & 0,01 & - & - & 0,00 & 0,00 \\
\hline Telšių & 100,00 & 89,53 & 7,87 & 0,36 & 0,61 & 1,58 & - & - & - & - & 0,05 \\
\hline Trakų & 100,00 & 90,38 & 5,54 & 0,13 & 1,02 & 2,77 & 0,00 & 0,16 & - & - & 0,00 \\
\hline Utenos & 100,00 & 87,90 & 7,41 & 0,09 & 2,83 & 1,76 & 0,00 & 0,01 & - & - & - \\
\hline Ukmergès & 100,00 & 90,61 & 6,51 & 0,10 & 1,63 & 1,11 & 0,01 & 0,03 & - & - & 0,00 \\
\hline Vilkaviškio & 100,00 & 74,75 & 8,98 & 14,98 & 0,01 & 1,19 & 0,00 & 0,00 & 0,01 & - & 0,08 \\
\hline Zarasų & 100,00 & 76,17 & 8,05 & 0,17 & 14,49 & 0,98 & - & 0,13 & - & - & - \\
\hline & & & & & & & & & & \\
\hline
\end{tabular}


A. Hermano žodžius patvirtina statistiniai duomenys apie Lietuvos evangelikų liuteronų dvasininkus. Jeigu nepriklausomybės pradžioje Lietuvoje evangelikų liuteronų dvasininkais dirbo vokiečiai, netgi nemokantys lietuvių kalbos ar neturintys teisès eiti dvasininko pareigas ${ }^{9}$, tai per du dešimtmečius situacija gerokai pasikeitè. Pirmiausia padaugejo lietuvių tautybès evangelikų liuteronų dvasininkų. $1937 \mathrm{~m}$. konsistorijos žinioje buvo 17 parapijų ir 34 filijos, jose veikè 20 ordinuotų kunigų: Lietuvos piliečių - 18, Latvijos piliečių - 1, Vokietijos - 1. Minimi kunigai aptarnavo 54016 parapijiečių (ị ši sąrašą galèjo nepatekti 2000-3000 evangelikų liuteronų tikybos asmenų) (žr. 3 lentelę). 1938 m. gegužès $1 \mathrm{~d}$. konsistorijos žinioje buvo 24 dvasininkai. Tautybės atžvilgiu jie pasiskirstė taip: lietuvių - 12, latvių - 4, vokiečių 8 (žr. 4 lentelę). Konsistorijos žiniomis, tuo metu dar vienas asmuo, lietuvių tautybès, buvo baigęs Teologijos fakultetą Vienoje ir konsistorijos nutarimu greitu laiku turéjo būti ordinuotas visateisiu Evangelikų Liuteronų Bažnyčios kunigu. Tuo laikotarpiu 9 studentai (8 lietuviai ir 1 latvis) užsienyje studijavo evangelikų teologiją kaip Švietimo ministerijos stipendininkai. Taigi netolimoje ateityje lietuvių evangelikų liuteronų dvasininkų skaičius dar turèjo išaugti ${ }^{10}$.

3 lentelè. Lietuvos Evangelikų Liuteronų Konsistorijos žinioje esančių parapijų ir filijų sąrašas (1937 m.) (Manoma, kad apie 2000-3000 evangelikų liuteronų nẻra patekę ị šį sąrašą. Pagal LCVA. F. 391. Ap. 4. B. 756. L. 135-137AV)

\begin{tabular}{|l|l|l|l|l|l|l|l|l|l|}
\hline $\begin{array}{l}\text { Eil. } \\
\text { nr. }\end{array}$ & $\begin{array}{l}\text { Parapi- } \\
\text { jos arba } \\
\text { filijos } \\
\text { pavadi- } \\
\text { nimas }\end{array}$ & $\begin{array}{l}\text { Parapi- } \\
\text { ja-filija }\end{array}$ & $\begin{array}{l}\text { Kiek turi } \\
\text { nuola- } \\
\text { tinių } \\
\text { parapi- } \\
\text { jiečiu }\end{array}$ & $\begin{array}{l}\text { Klebono } \\
\text { arba admi- } \\
\text { nistr. } \\
\text { pavarde ir } \\
\text { vardas }\end{array}$ & $\begin{array}{l}\text { Nuo kada } \\
\text { parapijai } \\
\text { arba filijai } \\
\text { vadovauja }\end{array}$ & Amžius & Pilietybé & Tautybé & $\begin{array}{l}\text { Mokslo } \\
\text { cenzas }\end{array}$ \\
\hline 1. & Ariogala & filija & 70 & $\begin{array}{l}\text { Kleb. kun. } \\
\text { Titelbachas } \\
\text { Povilas }\end{array}$ & $1892 . I I .7$ & 1865. XI.5 & Lietuvos & vokiečių & $\begin{array}{l}\text { Baigęs } \\
\text { Dorpato } \\
\text { universiteto } \\
\text { Teologijos } \\
\text { fakultetą }\end{array}$ \\
\hline 2. & Batakiai & parapija & 1200 & $\begin{array}{l}\text { Kun. Kileris } \\
\text { Adolfas }\end{array}$ & $\begin{array}{l}1935 . \\
\text { VII.20 }\end{array}$ & $\begin{array}{l}1906 . \\
\text { IX.14 }\end{array}$ & Lietuvos & lietuvių & $\begin{array}{l}\text { Baigęs } \\
\text { VDU } \\
\text { Teologijos } \\
\text { fakultetą }\end{array}$ \\
\hline 3. & Biržai & parapija & 100 & $\begin{array}{l}\text { Kleb. kun. } \\
\text { Leijeris } \\
\text { Erikas }\end{array}$ & $\begin{array}{l}1929 \text { m. } \\
\text { rudens }\end{array}$ & $1906 . I .18$ & Lietuvos & lietuvių & $\begin{array}{l}\text { Baigęs } \\
\text { VDU } \\
\text { Teologijos } \\
\text { fakultetą }\end{array}$ \\
\hline 4. & Būtingé & filija & 2100 & $\begin{array}{l}\text { Kun. Dagys } \\
\text { Petras }\end{array}$ & $1932 . V .1$ & $\begin{array}{l}1904 . \\
\text { III.15 }\end{array}$ & Lietuvos & lietuvių & $\begin{array}{l}\text { Baigęs } \\
\text { VDU } \\
\text { Teologijos } \\
\text { fakultetą }\end{array}$ \\
\hline 5. & Darbènai & filija & 60 & $\begin{array}{l}\text { Kleb. kun. } \\
\text { Gelžinis } \\
\text { Adomas }\end{array}$ & $1931 . X I .1$ & $1902 . I V .19$ & Lietuvos & lietuvių & $\begin{array}{l}\text { Baigęs } \\
\text { VDU } \\
\text { Teologijos } \\
\text { fakultetą }\end{array}$ \\
\hline
\end{tabular}




\begin{tabular}{|c|c|c|c|c|c|c|c|c|c|}
\hline $\begin{array}{l}\text { Eil. } \\
\text { nr. }\end{array}$ & $\begin{array}{l}\text { Parapi- } \\
\text { jos arba } \\
\text { filijos } \\
\text { pavadi- } \\
\text { nimas }\end{array}$ & $\begin{array}{l}\text { Parapi- } \\
\text { ja-filija }\end{array}$ & $\begin{array}{l}\text { Kiek turi } \\
\text { nuola- } \\
\text { tinių } \\
\text { parapi- } \\
\text { jiečių }\end{array}$ & $\begin{array}{l}\text { Klebono } \\
\text { arba admi- } \\
\text { nistr. } \\
\text { pavardè ir } \\
\text { vardas }\end{array}$ & $\begin{array}{l}\text { Nuo kada } \\
\text { parapijai } \\
\text { arba filijai } \\
\text { vadovauja }\end{array}$ & Amžius & Pilietybè & Tautybè & $\begin{array}{l}\text { Mokslo } \\
\text { cenzas }\end{array}$ \\
\hline 6. & Elkiškiai & parapija & 1500 & \begin{tabular}{|l|} 
Kun. \\
Rauskinas \\
Gustavas \\
\end{tabular} & 1932.X.1 & 1901.XII.6 & Latvijos & latvių & \begin{tabular}{|l|} 
Kunigu \\
ordinuotas \\
Latvijoje
\end{tabular} \\
\hline 7. & Gargždai & filija & 200 & $\begin{array}{l}\text { Kleb. kun. } \\
\text { Gelžinis } \\
\text { Adomas }\end{array}$ & 1931.XI.1 & 1902.IV.19 & Lietuvos & lietuvių & $\begin{array}{l}\text { Baigęs } \\
\text { VDU } \\
\text { Teologijos } \\
\text { fakultetą }\end{array}$ \\
\hline 8. & Garliava & parapija & 1500 & $\begin{array}{l}\text { Kun. Vyme- } \\
\text { ris Rudolfas }\end{array}$ & $\begin{array}{l}1935 \mathrm{~m} . \\
\text { rudens }\end{array}$ & $\begin{array}{l}1906 . \\
\text { VIII.13 }\end{array}$ & Lietuvos & lietuvių & \begin{tabular}{|l|} 
Baigęs \\
VDU \\
Teologijos \\
fakultetą
\end{tabular} \\
\hline 9. & Ylakiai & filija & 80 & $\begin{array}{l}\text { Kun. } \\
\text { Laukozilis } \\
\text { Arnoldas }\end{array}$ & 1936.I.1 & $\begin{array}{l}1901 . \\
\text { IX.13 }\end{array}$ & Lietuvos & latvių & \begin{tabular}{|l|} 
Baigęs \\
VDU \\
Teologijos \\
fakultetą
\end{tabular} \\
\hline 10. & Joniškis & filija & 700 & \begin{tabular}{|l|} 
Kun. \\
Rauskinas \\
Gustavas
\end{tabular} & 1932.X.1 & 1901.XI.6 & Latvijos & latvių & \begin{tabular}{|l} 
Kunigu \\
ordinuotas \\
Latvijoje
\end{tabular} \\
\hline 11. & Jurbarkas & parapija & 3000 & $\begin{array}{l}\text { Kun. Jèkelis } \\
\text { Hermanas }\end{array}$ & \begin{tabular}{|l}
1933. \\
VI.10
\end{tabular} & $\begin{array}{l}1901 . \\
\text { XII.17 }\end{array}$ & Lietuvos & vokiečių & $\begin{array}{l}\text { Baigęs } \\
\text { VDU } \\
\text { Teologijos } \\
\text { fakultetą }\end{array}$ \\
\hline 12. & Kalvarija & filija & 1200 & $\begin{array}{l}\text { Kleb. kun. } \\
\text { Eichelber- } \\
\text { geris Emilis }\end{array}$ & $1894 \mathrm{~m}$. & $\begin{array}{l}1865 . \\
\text { VI.26 }\end{array}$ & Lietuvos & vokiečių & \begin{tabular}{|l|} 
Baigęs \\
Dorpato \\
universiteto \\
Teologijos \\
fakultetą
\end{tabular} \\
\hline 13. & Kaunas & parapija & 4300 & $\begin{array}{l}\begin{array}{l}\text { Kun. Paupe- } \\
\text { ras Jonas }\end{array} \\
\begin{array}{l}\text { Kun. Više- } \\
\text { ropas Jonas }\end{array}\end{array}$ & 1935.XI.1 & $\begin{array}{l}1894 . \\
\text { VIII.7 }\end{array}$ & $\begin{array}{l}\text { Vokieti- } \\
\text { jos }\end{array}$ & lietuvių & \begin{tabular}{|l} 
Baigęs \\
VDU \\
Teologijos \\
fakultetą \\
\\
Baigęs \\
Halès \\
universiteto \\
Teologijos \\
fakultetą
\end{tabular} \\
\hline 14. & Kèdainiai & parapija & 150 & $\begin{array}{l}\text { Kleb. kun. } \\
\text { Titelbachas } \\
\text { Povilas }\end{array}$ & 1892.II.7 & 1865.XI.5 & Lietuvos & vokiečių & \begin{tabular}{|l|} 
Baigęs \\
Dorpato \\
universiteto \\
Teologijos \\
fakultetą
\end{tabular} \\
\hline 15. & Kelmé & filija & 300 & $\begin{array}{l}\text { Kun. Kileris } \\
\text { Adolfas }\end{array}$ & 1936.VI.1 & $\begin{array}{l}1906 . \\
\text { IX.14 }\end{array}$ & Lietuvos & lietuvių & \begin{tabular}{|l|} 
Baigęs \\
VDU \\
Teologijos \\
fakultetą
\end{tabular} \\
\hline
\end{tabular}




\begin{tabular}{|c|c|c|c|c|c|c|c|c|c|}
\hline $\begin{array}{l}\text { Eil. } \\
\text { nr. }\end{array}$ & $\begin{array}{l}\text { Parapi- } \\
\text { jos arba } \\
\text { filijos } \\
\text { pavadi- } \\
\text { nimas }\end{array}$ & $\begin{array}{l}\text { Parapi- } \\
\text { ja-filija }\end{array}$ & $\begin{array}{l}\text { Kiek turi } \\
\text { nuola- } \\
\text { tinių } \\
\text { parapi- } \\
\text { jiečių }\end{array}$ & $\begin{array}{l}\text { Klebono } \\
\text { arba admi- } \\
\text { nistr. } \\
\text { pavardè ir } \\
\text { vardas }\end{array}$ & $\begin{array}{l}\text { Nuo kada } \\
\text { parapijai } \\
\text { arba filijai } \\
\text { vadovauja }\end{array}$ & Amžius & Pilietybè & Tautybe் & $\begin{array}{l}\text { Mokslo } \\
\text { cenzas }\end{array}$ \\
\hline 16. & Kybartai & filija & 1800 & $\begin{array}{l}\text { Kun. Landi- } \\
\text { gas Bruno }\end{array}$ & 1936.X.1 & 1909.I.2 & Lietuvos & vokiečių & $\begin{array}{l}\text { Baigęs } \\
\text { VDU } \\
\text { Teologijos } \\
\text { fakultetą }\end{array}$ \\
\hline 17. & Kretinga & parapija & 1040 & $\begin{array}{l}\text { Kleb. kun. } \\
\text { Gelžinis } \\
\text { Adomas }\end{array}$ & 1931.XI.1 & 1902.IV.19 & Lietuvos & lietuvių & \begin{tabular}{|l|} 
Baigęs \\
VDU \\
Teologijos \\
fakultetą
\end{tabular} \\
\hline 18. & Kuršènai & filija & 159 & $\begin{array}{l}\text { Kleb. kun. } \\
\text { Kupfertas } \\
\text { Teodoras }\end{array}$ & 1904.VI.1 & 1869.IV.11 & Lietuvos & vokiečių & $\begin{array}{l}\text { Baigęs } \\
\text { Dorpato } \\
\text { universiteto } \\
\text { Teologijos } \\
\text { fakultetą }\end{array}$ \\
\hline 19. & $\begin{array}{l}\text { Marijam- } \\
\text { polè }\end{array}$ & parapija & 2000 & $\begin{array}{l}\text { Kleb. kun. } \\
\text { Eichelber- } \\
\text { geris Emilis }\end{array}$ & $1894 \mathrm{~m}$. & $\begin{array}{l}1865 . \\
\text { VI.26 }\end{array}$ & Lietuvos & vokiečių & \begin{tabular}{|l} 
Baigęs \\
Dorpato \\
universiteto \\
Teologijos \\
fakultetą
\end{tabular} \\
\hline 20. & $\begin{array}{l}\text { Mažei- } \\
\text { kiai }\end{array}$ & filija & 863 & $\begin{array}{l}\text { Kleb. kun. } \\
\text { Kupfertas } \\
\text { Teodoras }\end{array}$ & 1904.VI.1 & 1869.IV.11 & Lietuvos & vokiečių & \begin{tabular}{|l} 
Baigęs \\
Dorpato \\
universiteto \\
Teologijos \\
fakultetą
\end{tabular} \\
\hline 21. & $\begin{array}{l}\text { Nau- } \\
\text { miestis, } \\
\text { Kudirkos }\end{array}$ & filija & 1000 & $\begin{array}{l}\text { Superint. } \\
\text { kun. Sroka } \\
\text { Dzer- } \\
\text { žislovas } \\
\text { Henrikas } \\
\end{array}$ & 1928.XI.1 & $\begin{array}{l}1858 . \\
\text { VII.16 }\end{array}$ & Lietuvos & lietuvių & $\begin{array}{l}\text { Baigęs } \\
\text { Dorpato } \\
\text { universiteto } \\
\text { Teologijos } \\
\text { fakultetą }\end{array}$ \\
\hline 22. & $\begin{array}{l}\text { Nau- } \\
\text { miestis, } \\
\text { Tauragès }\end{array}$ & filija & 2500 & $\begin{array}{l}\text { Prof. kun. } \\
\text { Gaigalaitis } \\
\text { Vilius }\end{array}$ & $\begin{array}{l}1936 . \\
\text { VI.15 }\end{array}$ & $\begin{array}{l}1910 . \\
\text { IX.27 }\end{array}$ & Lietuvos & lietuvių & $\begin{array}{l}\text { Baigęs } \\
\text { Univer- } \\
\text { siteto }^{11} \text {, } \\
\text { Teologijos } \\
\text { fakultetą }\end{array}$ \\
\hline 23. & Pabalvė & filija & 91 & $\begin{array}{l}\text { Kleb. kun. } \\
\text { Kupfertas } \\
\text { Teodoras }\end{array}$ & $1904 \mathrm{~m}$. & 1969.IV.11 & Lietuvos & vokiečiu & \begin{tabular}{|l} 
Baigęs \\
Dorpato \\
universiteto \\
Teologijos \\
fakultetą
\end{tabular} \\
\hline 24. & Pakruojis & filija & 300 & $\begin{array}{l}\text { Kun. } \\
\text { Vagneris } \\
\text { Gustavas }\end{array}$ & $\begin{array}{l}1938 \mathrm{~m} . \\
\text { pavasario }\end{array}$ & 1907.X.20 & Lietuvos & lietuvių & \begin{tabular}{|l} 
Baigęs \\
VDU \\
Teologijos \\
fakultetą
\end{tabular} \\
\hline 25. & Palanga & filija & 100 & $\begin{array}{l}\text { Kleb. kun. } \\
\text { Gelžinis } \\
\text { Adomas }\end{array}$ & 1931.XI.1 & 1902.IV.19 & Lietuvos & lietuvių & \begin{tabular}{|l|} 
Baigęs \\
VDU \\
Teologijos \\
fakultetą
\end{tabular} \\
\hline
\end{tabular}




\begin{tabular}{|c|c|c|c|c|c|c|c|c|c|}
\hline $\begin{array}{l}\text { Eil. } \\
\text { nr. }\end{array}$ & $\begin{array}{l}\text { Parapi- } \\
\text { jos arba } \\
\text { filijos } \\
\text { pavadi- } \\
\text { nimas }\end{array}$ & $\begin{array}{l}\text { Parapi- } \\
\text { ja-filija }\end{array}$ & $\begin{array}{l}\text { Kiek turi } \\
\text { nuola- } \\
\text { tinių } \\
\text { parapi- } \\
\text { jiečių }\end{array}$ & $\begin{array}{l}\text { Klebono } \\
\text { arba admi- } \\
\text { nistr. } \\
\text { pavardè ir } \\
\text { vardas }\end{array}$ & $\begin{array}{l}\text { Nuo kada } \\
\text { parapijai } \\
\text { arba filijai } \\
\text { vadovauja }\end{array}$ & Amžius & Pilietybè & Tautybe் & $\begin{array}{l}\text { Mokslo } \\
\text { cenzas }\end{array}$ \\
\hline 26. & Pandèlys & filija & 150 & $\begin{array}{l}\text { Kleb. kun. } \\
\text { Leijeris } \\
\text { Erikas }\end{array}$ & $\begin{array}{l}1929 \mathrm{~m} . \\
\text { rudens }\end{array}$ & 1906.V.18 & Lietuvos & lietuvių & $\begin{array}{l}\text { Baigęs } \\
\text { VDU } \\
\text { Teologijos } \\
\text { fakultetą }\end{array}$ \\
\hline 27. & $\begin{array}{l}\text { Panevè- } \\
\text { žys }\end{array}$ & parapija & 300 & $\begin{array}{l}\text { Kun. Hir- } \\
\text { šas-Girša } \\
\text { Albertas }\end{array}$ & 1936.II.1 & $\begin{array}{l}1908 . \\
\text { IX.26 }\end{array}$ & Lietuvos & vokiečių & $\begin{array}{l}\text { Baigęs } \\
\text { VDU } \\
\text { Teologijos } \\
\text { fakultetą }\end{array}$ \\
\hline 28. & Pilviškiai & filija & 400 & $\begin{array}{l}\text { Kleb. kun. } \\
\text { Eichelber- } \\
\text { geris Emilis }\end{array}$ & $1894 \mathrm{~m}$. & $\begin{array}{l}1865 . \\
\text { VI.26 }\end{array}$ & Lietuvos & vokiečių & $\begin{array}{l}\text { Baigęs } \\
\text { Dorpato } \\
\text { universiteto } \\
\text { Teologijos } \\
\text { fakultetą }\end{array}$ \\
\hline 29. & Prienai & filija & 900 & $\begin{array}{l}\text { Kun. Vyme- } \\
\text { ris Rudolfas }\end{array}$ & $\begin{array}{l}1935 \mathrm{~m} . \\
\text { rudens }\end{array}$ & $\begin{array}{l}1906 . \\
\text { VIII.3 }\end{array}$ & Lietuvos & lietuvių & $\begin{array}{l}\text { Baigęs } \\
\text { VDU } \\
\text { Teologijos } \\
\text { fakultetą } \\
\end{array}$ \\
\hline 30. & $\begin{array}{l}\text { Radviliš- } \\
\text { kis }\end{array}$ & filija & 170 & $\begin{array}{l}\text { Kleb. kun. } \\
\text { Kupfertas } \\
\text { Teodoras }\end{array}$ & 1904.VI.1 & 1869.IV.11 & Lietuvos & vokiečių & $\begin{array}{l}\text { Baigęs } \\
\text { Dorpato } \\
\text { universiteto } \\
\text { Teologijos } \\
\text { fakultetą }\end{array}$ \\
\hline 31. & Raseiniai & filija & 1000 & $\begin{array}{l}\text { Kun. Jekelis } \\
\text { Hermanas }\end{array}$ & $1931 \mathrm{~m}$. & $\begin{array}{l}1901 . \\
\text { XI.17 }\end{array}$ & Lietuvos & vokiečių & \begin{tabular}{|l} 
Baigęs \\
VDU \\
Teologijos \\
fakultetą
\end{tabular} \\
\hline 32. & Ritinè & filija & 100 & $\begin{array}{l}\text { Kun. } \\
\text { Laukozilis } \\
\text { Arnoldas }\end{array}$ & 1936.I.I & $\begin{array}{l}1909 . \\
\text { XI.13 }\end{array}$ & Lietuvos & latvių & \begin{tabular}{|l|} 
Baigęs \\
VDU \\
Teologijos \\
fakultetą
\end{tabular} \\
\hline 33. & $\begin{array}{l}\text { Sartinin- } \\
\text { kai }\end{array}$ & filija & 600 & $\begin{array}{l}\text { Kleb. kun. } \\
\text { Vymeris } \\
\text { Augustas }\end{array}$ & 1911.V.1 & $\begin{array}{l}1869 . \\
\text { XII.16 }\end{array}$ & Lietuvos & vokiečių & \begin{tabular}{|l|} 
Baigęs \\
Dorpato \\
universiteto \\
Teologijos \\
fakultetą \\
\end{tabular} \\
\hline 34. & Seirijai & filija & 500 & $\begin{array}{l}\text { Kleb. kun. } \\
\text { Eichelber- } \\
\text { geris Emilis }\end{array}$ & $1894 \mathrm{~m}$. & $\begin{array}{l}1865 . \\
\text { VI.26 }\end{array}$ & Lietuvos & vokiečių & \begin{tabular}{|l} 
Baigęs \\
Dorpato \\
universiteto \\
Teologijos \\
fakultetą \\
\end{tabular} \\
\hline 35. & Skaudvilè & filija & 460 & $\begin{array}{l}\text { Kleb. kun. } \\
\text { Vymeris } \\
\text { Augustas }\end{array}$ & 1911.V.1 & $\begin{array}{l}1869 . \\
\text { XII.16 }\end{array}$ & Lietuvos & vokiečiuc & \begin{tabular}{|l} 
Baigęs \\
Dorpato \\
universiteto \\
Teologijos \\
fakultetą
\end{tabular} \\
\hline
\end{tabular}




\begin{tabular}{|c|c|c|c|c|c|c|c|c|c|}
\hline $\begin{array}{l}\text { Eil. } \\
\text { nr. }\end{array}$ & $\begin{array}{l}\text { Parapi- } \\
\text { jos arba } \\
\text { filijos } \\
\text { pavadi- } \\
\text { nimas }\end{array}$ & $\begin{array}{l}\text { Parapi- } \\
\text { ja-filija }\end{array}$ & $\begin{array}{l}\text { Kiek turi } \\
\text { nuola- } \\
\text { tinių } \\
\text { parapi- } \\
\text { jiečių }\end{array}$ & $\begin{array}{l}\text { Klebono } \\
\text { arba admi- } \\
\text { nistr. } \\
\text { pavardè ir } \\
\text { vardas }\end{array}$ & $\begin{array}{l}\text { Nuo kada } \\
\text { parapijai } \\
\text { arba filijai } \\
\text { vadovauja }\end{array}$ & Amžius & Pilietybe் & Tautybè & $\begin{array}{l}\text { Mokslo } \\
\text { cenzas }\end{array}$ \\
\hline 36. & Skuodas & parapija & 600 & $\begin{array}{l}\text { Kun. } \\
\text { Laukozilis } \\
\text { Arnoldas }\end{array}$ & 1936.I.1 & $\begin{array}{l}1909 . \\
\text { XII.13 }\end{array}$ & Lietuvos & latvių & $\begin{array}{l}\text { Baigęs } \\
\text { VDU } \\
\text { Teologijos } \\
\text { fakultetą }\end{array}$ \\
\hline 37. & Sudargas & filija & 1500 & $\begin{array}{l}\text { Kun. Jekelis } \\
\text { Hermanas }\end{array}$ & $\begin{array}{l}1933 . \\
\text { VI.20 }\end{array}$ & $\begin{array}{l}1901 . \\
\text { XII.17 }\end{array}$ & Lietuvos & vokiečių & $\begin{array}{l}\text { Baigęs } \\
\text { VDU } \\
\text { Teologijos } \\
\text { fakultetą }\end{array}$ \\
\hline 38. & Šakiai & parapija & 2000 & $\begin{array}{l}\text { Superint. } \\
\text { kun. Sroka } \\
\text { Dzer- } \\
\text { žislovas } \\
\text { Henrikas } \\
\end{array}$ & $1885 \mathrm{~m}$. & $\begin{array}{l}1858 . \\
\text { VII.16 }\end{array}$ & Lietuvos & lietuvių & $\begin{array}{l}\text { Baigęs } \\
\text { Dorpato } \\
\text { universiteto } \\
\text { Teologijos } \\
\text { fakultetą } \\
\end{array}$ \\
\hline 39. & Šeduva & filija & 100 & $\begin{array}{l}\text { Kun. Hir- } \\
\text { šas-Girša } \\
\text { Albertas }\end{array}$ & 1936.II.1 & $\begin{array}{l}1908 . \\
\text { IX.26 }\end{array}$ & Lietuvos & vokiečių & $\begin{array}{l}\text { Baigęs } \\
\text { VDU } \\
\text { Teologijos } \\
\text { fakultetą }\end{array}$ \\
\hline 40. & Šiauliai & parapija & 510 & $\begin{array}{l}\text { Kleb. kun. } \\
\text { Kupfertas } \\
\text { Teodoras }\end{array}$ & $1904 \mathrm{~m}$. & 1869.IV.11 & Lietuvos & vokiečių & $\begin{array}{l}\text { Baigęs } \\
\text { Dorpato } \\
\text { universiteto } \\
\text { Teologijos } \\
\text { fakultetą }\end{array}$ \\
\hline 41. & Šilalè & filija & 800 & $\begin{array}{l}\text { Kleb. kun. } \\
\text { Vymeris } \\
\text { Augustas }\end{array}$ & 1911.V.11 & $\begin{array}{l}1869 . \\
\text { XII.16 }\end{array}$ & Lietuvos & vokiečių & \begin{tabular}{|l} 
Baigęs \\
Dorpato \\
universiteto \\
Teologijos \\
fakultetą
\end{tabular} \\
\hline 42. & Švèkšna & filija & 500 & $\begin{array}{l}\text { Kleb. kun. } \\
\text { Gelžinis } \\
\text { Adomas }\end{array}$ & $\begin{array}{l}1934 . \\
\text { VIII.1 }\end{array}$ & 1902.IV.19 & Lietuvos & lietuvių & $\begin{array}{l}\text { Baigęs } \\
\text { VDU } \\
\text { Teologijos } \\
\text { fakultetą }\end{array}$ \\
\hline 43. & Tauragè & parapija & 7500 & $\begin{array}{l}\text { Kleb. kun. } \\
\text { Vymeris } \\
\text { Augustas }\end{array}$ & 1911.V.1 & $\begin{array}{l}1869 . \\
\text { XII.16 }\end{array}$ & Lietuvos & vokiečių & \begin{tabular}{|l|} 
Baigęs \\
Dorpato \\
universiteto \\
Teologijos \\
fakultetą \\
\end{tabular} \\
\hline 44. & Telšiai & filija & 70 & $\begin{array}{l}\text { Kun. } \\
\text { Laukozilis } \\
\text { Arnoldas }\end{array}$ & 1936.I.1 & $\begin{array}{l}1909 . \\
\text { XII.13 }\end{array}$ & Lietuvos & latvių & $\begin{array}{l}\text { Baigęs } \\
\text { VDU } \\
\text { Teologijos } \\
\text { fakultetą }\end{array}$ \\
\hline 45. & Ukmergè & filija & 35 & $\begin{array}{l}\text { Kleb. kun. } \\
\text { Titelbachas } \\
\text { Povilas }\end{array}$ & 1892.II.7 & 1865.XII.5 & Lietuvos & vokiečių & \begin{tabular}{|l} 
Baigęs \\
Dorpato \\
universiteto \\
Teologijos \\
fakultetą
\end{tabular} \\
\hline
\end{tabular}




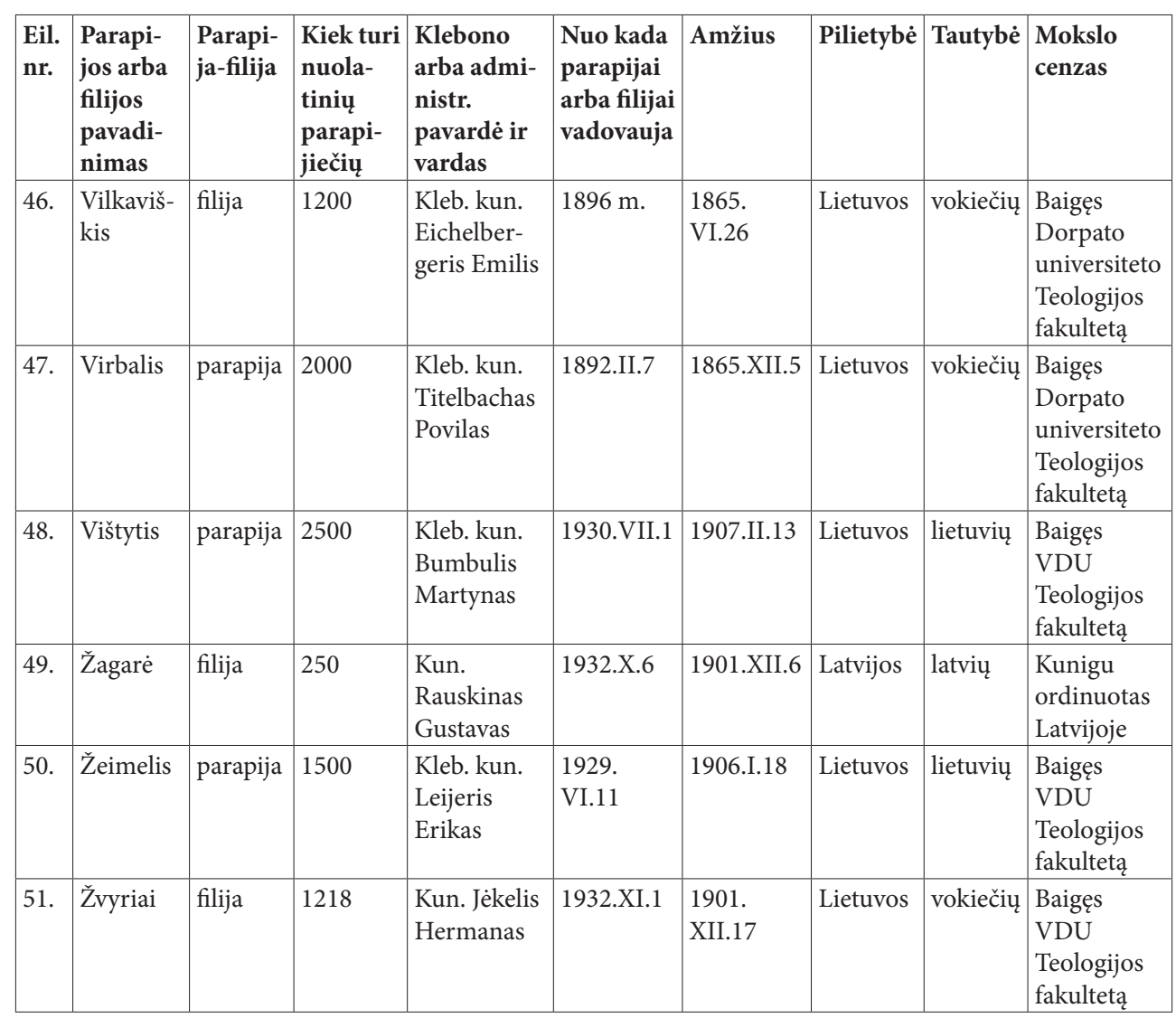

Iš viso 54016

4 lentelé. Lietuvos Evang. Liut. Konsistorijos žinioje esančių dvasininkų sąrašas [1938 m.] (Lentelè sudaryta remiantis: Konsistorijos reikalų vedẻjas. Lietuvos Evang. Liut. Konsistorijos žinioje esančių dvasininkų sąrašas // LCVA. F. 391. Ap. 4. B. 760. L. 89.)

\begin{tabular}{|c|l|l|l|}
\hline Eil. nr. & Vardas ir pavardė & Tautybe் & Gyvenamoji vieta \\
\hline 1. & Sup. kun. Henrikas Sroka & lietuvių & Šakiai \\
\hline 2. & Teol. lic. kun. Jonas Pauperas & lietuvių & Kaunas \\
\hline 3. & Prof. dr. kun. Vilius Gaigalaitis & lietuvių & Gargždai-Klaipėda \\
\hline 4. & Kun. Erikas Leijeris & lietuvių & Žeimelis \\
\hline 5. & Kun. Martynas Bumbulis & lietuvių & Vištytis \\
\hline 6. & Kun. sen. Adomas Gelžinis & lietuvių & Kretinga \\
\hline 7. & Kun. Petras Dagys & lietuvių & Butingè-Kretinga \\
\hline 8. & Kun. Gustavas Vagneris & lietuvių & Raseiniai-Pagègiai \\
\hline 9. & Kun. Rudolfas Vymeris & lietuvių & Garliava-Prienai \\
\hline 10. & Kun. Adolfas Kileris & lietuvių & Batakiai \\
\hline 11. & Kun. Martynas Preikšaitis & lietuvių & Sudargas \\
\hline
\end{tabular}




\begin{tabular}{|c|l|l|l|}
\hline Eil. nr. & Vardas ir pavardė & Tautybė & Gyvenamoji vieta \\
\hline 12. & Kun. Julius Stanaitis & lietuvių & Jurbarkas \\
\hline 13. & Kun. sen. Arnoldas Laukozilis & latvių & Skuodas \\
\hline 14. & Kun. Gustavas Rauskinas & latvių & Elkiškiai \\
\hline 15. & Kun. Juozas Urdzė & latvių & Biržai \\
\hline 16. & Mis. diak. Fridrikas Megne & latvių & Seirijai-Laugaliai \\
\hline 17. & Kun. sen. Povilas Titelbachas & vokiečių & Virbalis \\
\hline 18. & Kun. Emilis Eichelbergeris & vokiečių & Marijampolė \\
\hline 19. & Kun. Teodoras Kupfertas & vokiečių & Šiauliai \\
\hline 20. & Kun. Augustas Vymeris & vokiečių & Tauragé \\
\hline 21. & Kun. Jonas Višeropas & vokiečių & Kaunas \\
\hline 22. & Kun. Hermanas Jèkelis & vokiečių & Ž. Naumiestis \\
\hline 23. & Kun. Albertas Hiršas & vokiečių & Panevėžys \\
\hline 24. & Kun. Bruno Landingas & vokiečių & Kybartai \\
\hline
\end{tabular}

Lietuvių tautybės evangelikų liuteronų dvasininkų gausẻjimą lėmé Lietuvos valdžios pastangos ịvairiomis priemonėmis stiprinti lietuvybę tarp evangelikų liuteronų. Vadovautasi nuostata: „Jeigu evangelikų-liuteronų parapijose daugiau kunigų lietuvių, tai ir jų sulietuvinimas pasistūmètų pirmyn. Dabar jų kunigai lietuviškumo visai neskiepija. Toks evangelikų-vokiečių lietuvinimo darbas nieko nežada"12. Kaip bus rašoma, valdžia i̇dèjo daug pastangų, kad Evangelikų liuteronų konsistorijos vadovybè rūpintųsi lietuvybès skleidimu, o kartu mažintų germanizacijos ịtaką evangelikų liuteronų parapijose. Lietuvybès skleidimui daug ittakos turejjo Evangelikų teologijos fakulteto įsteigimas Lietuvos universitete (1930 m. jis buvo pavadintas Vytauto Didžiojo universitetu) Kaune. 1925-1936 m. veikusiame Lietuvos (Vytauto Didžiojo) universiteto Evangelikų teologijos fakultete 32 studentai išlaikè minèto fakulteto reglamento nustatytus egzaminus ir gavo mokslo baigimo diplomus - tarp jų 9 reformatai ir 23 liuteronai (13 lietuvių, 3 latviai ir 7 vokiečiai) ${ }^{13}$. Vokiečių evangelikų sinodas nenorejjo, kad šis fakultetas veiktų, nes ji baigę jaunuoliai parapijose, kuriose dirbo, skiepijo lietuviškumą, o tai darè vietos evangelikus labiau tautiškai susipratusius lietuvybès požiūriu. Lietuviai evangelikai liuteronai laikèsi nuomonès, kad Evangelikų teologijos fakultetas tiesiog privalo išlikti universitete. Memorandume Evangelikų teologijos fakulteto likimo reikalu (dokumentą $1928 \mathrm{~m}$. liepos $25 \mathrm{~d}$. pasirašè Lietuvos evang. liuter. konsistorijos prezidentas Vilius Gaigalaitis ir prokuroras Martynas Kavolis, Lietuvių sinodo vicesenjoras superintendentas kun. Henrikas Dzeržislovas Sroka ir narys Mikas Preikšaitis, Lietuvių ir latvių sinodo prezidiumo narys Liudas Bendaravičius, Lietuvių evang. reformatų superintendentas kun. Povilas Jakubènas ir kuratorius Matynas Yčas, Lietuvių evang. liuter. sąungos „Pagalba“ pirmininkas Kristupas Gudaitis, Klaipedos krašto lietuvių draugijos „Sandora“ atstovas Kubilius ir Lietuvos latvių sajungos atstovas Namikas) Lietuvos valdžios prašyta neuždaryti Kaune, Lietuvos universitete, 2,5 metų veikiančio Teologijos fakulteto. Memorandumo autoriai savo nuomonę grinde šiais argumentais: 1) Klaipėdos krašte bei Didžiojoje Lietuvoje tarp evangelikų liuteronų vykdoma didelè germanizacija, nes trūksta lietuvių evangelikų liuteronų kunigų („Didžiojoje Lietuvoje iš viso yra 22 parapijos ir 27 filijos, o kunigų yra tik 6, kurių 
tik vienas lietuvių tautybès, pirmas baigęs Lietuvos universiteto Evangelikų Teologijos fakultetą. Be jų Lietuvoje kunigauja dar trys svetimšaliai, neturi tam reikalingo leidimo ir 2 misionieriai, neturi atitinkamo mokslo cenzo. Be to keli užsienio piliečiai, nesiskaitydami su Lietuvos valdžia, ịsibrovę uzurpatorišku būdu, prieš konsistorijos ir parapijų norą tūlose parapijose eina kunigų pareigas. Parapijonių dauguma yra lietuvių kilimo su grynai lietuviškomis pavardèmis, bet jų daugelis per kunigus suvokietinti“"14), todèl vokiečiai deda daug pastangų, kad jaunuoliai ị šị universitetą nestotų: fakultetą steigiant ir ji įsteigus, vokiečiai prieš jị varydavo ịvairią akciją, net atkalbinėdavo kviečiamus iš užsienio docentus, nes jautė, kad Lietuvoj, galint ruošti savus kunigus, parapijų valdymas greit pereis iš vokiečių rankų ir bus užkirstas kelias vokietinimui. Klaipèdos krašte vokiečiai atkalbinejo jaunuolius stoti ị ši fakultetą ir duodavo lèšu stipendijoms ir bendrabučiams; 2) Evangelikų Teologijos fakultete yra pakankamas skaičius studentų 19: Neimanas, Vymeris, Jèkelis, Stanaitis, Lejeris, Mizeras, Barnelis, Biržys, Žemaitis, Grybė, Kurnatauskas, Bumbulis, Geležinis, Paupuras (3 klaipèdiškiai), Preikšaitis, Balčauskas, Dagys, Šernas ir Lokys (klaipédiškis). Priminta, jog toks studentų skaičius nėra mažas palyginti su kitais ir senais užsienio universitetų teologijos studentais, pvz., Berne ir Bazelyje būdavo 10-15 teologijos studentų, o profesorių būdavo triskart tiek, kiek Lietuvoje; 3) baigusieji Evangelikų Teologijos fakultetą jaunieji kunigai turi didelį autoritetą visuomenèje. Nurodytas studijas baigusio studento Lokio atvejis, kai šis vos baigęs universitetą nepaprastai dideliu balsų skaičiumi, be jokios opozicijos, buvo išrinktas kunigu beveik grynai suvokietintos parapijos Virbalyje, kur pamaldos būdavo laikomos vien vokiečių kalba; 4) Vien studijų telkimas užsienio universitetuose neatstos savo aukštosios mokyklos, nes užsienio universitetai Lietuvos studentams sunkiai prieinami dẻl kelių priežasčių: a) reikia gerai išmokti to krašto kalbą (jos sugrižžus ị namus, neteks vartoti, o jos nemokant, bendrai nebus galima studijuoti), mokèti lotynų, graikų ir vietomis net hebrajų kalbas; b) vos tik gimnaziją baigęs jaunuolis, atsidūręs užsienyje, nutolsta nuo savo krašto ir žmonių, todèl namo sugrižžęs nebesupranta savo gyvenimo ir nebegali arba nebenori prie jo prisitaikyti. Be to, teologams, baigus užsieny mokslą, ir svetima kalba mokslą igijus sunkus bus, nežinant lietuviškų terminų, žinias praktikoj pritaikyti; 5) Esamieji evangelikų liuteronų tarpe ginčai savaime baigsis, išleidus savos mokslo ịstaigos kunigus; 6) Panaikinus Evangelikų Teologijos fakultetą, be jokių valstybių egzaminų bus leidžiama Lietuvoje kunigauti kiekvienam, kuris yra studijavęs bet kuriame užsienio universitete, kur iš jų nereikalaujama jokių valstybinių egzaminų; 7) Evangelikų Teologijos fakulteto išlaikymas valstybei didelių išlaidų nesudaro, nes turi tik 5 katedras, o bendrų dalykų studentai klausosi Humanitarinių mokslų fakultete. Jeigu šiam fakultetui valdžios subsidijuojamos išlaidos atrodytų per didelès, tai galima būtų paieškoti porai docentų apmokèti pinigų iš užsienio evangelikų organizacijų; 8) Panaikinus Evangelikų Teologijos fakultetą bus padaryta didelè evangelikams skriauda (jos nebus galima kompensuoti jokiomis stipendijomis) ir „iš to išeis tik vokietininkų triumfas“. Be to, panaikinus fakultetą, tarptautiniu mastu susidarys ịspūdis, jog Lietuvoje evangelikai yra persekiojami ir šalyje veikia religinè netolerancija ${ }^{15}$. Tą kartą valdžia atsižvelgè ì memorandume Evangelikų liuteronų konsistorijos (iš jos savo noru buvo pasitraukę vokiečių evangelikų liuteronų atstovai) išsakytą nuomonę ir Evangelikų teologijos fakultetas paliktas dar keletą metų veikti. Kad Evangelikų teologijos fakultetas 
daug prisidèjo prie lietuvių evangelikų liuteronų dvasininkų parengimo, taikliai iliustruoja pateikti statistiniai duomenys (žr. 3 lentelę) - didžioji dalis lietuvių evangelikų liuteronų dvasininkų buvo jauni ir studijas baigè VDU Teologijos fakultete.

\section{Vokiečių ir lietuvių evangelikų liuteronų pozicijų skirtumai}

1919 m. spalio 15 d., tarpininkaujant Tikybų departamentui, Kaune įvyko pirmasis Evangelikų Liuteronų Bažnyčios steigiamasis sinodas, kuris išryškino jame dalyvavusių tautinių grupių atstovų nesutarimus („Čia tuojau iškilo ginčas, kuria kalba sinodas turi būti vedamas. Lietuviai griežtai reikalavo, kad būtų kalbama lietuviškai, ir kad tas asmuo, kuris stovès Bažnyčios priešakyje, mokètų gerai lietuvių kalbą <...> Vokiečiai, ypač kai kurie kunigai, su tuo nesutiko. Tada iš vokiečių puses buvo sugalvota sudaryti tris sinodus: lietuvių, latvių ir vokiečių "16). Gal ši nesantaika, kilusi iš kalbos vartojimo konflikto, tebuvo formalaus pobūdžio - tai greičiausiai buvo užslèpta kova dèl būsimos lyderystès Evangelikų Liuteronų Bažnyčioje. Nuo 1920 m. lietuvių, latvių ir vokiečių sinodai vykdavo atskirai. Minètųų sinodų rinkti ( 1 dvasiškis ir 1 pasaulietis) 3 kunigai senjorai ir 3 pasauliečiai sudarè Evangelikų liuteronų konsistoriją, kuri buvo Bažnyčios aukščiausiasis vykdomasis organas. Prezidentą ir viceprezidentą iš sinodo atstovų skirdavo valstybès prezidentas ${ }^{17}$.

Nuo 1921 m. vykstantys atskiri lietuvių, latvių ir vokiečių sinodai skaldẻ Bažnyčios vienybę ir sunkino jos veiklą. Visos Evangelikų Liuteronų Bažnyčios parapijos buvo mišrios (išskyrus Batakių ir Skaudvilès folijas - 1935 m.), parapijiečiai bendrai naudojosi bažnyčia ir jos turtu, tarybos buvo bendros, jų nariai rinkti proporcingai nuo kiekvienos tautybès parapijiečių skaičiaus. Todèl skyrèsi vokiečiu bendruomenès, vokiečių sinodo (iš vienos pusès) ir Evangelikų Liuteronų Bažnyčios vadovybę išrenkančios valdžios pozicija bei vizijos. Vokiečių evangelikų sinodas ir jo atstovai Evangelikų liuteronų konsistorijoje siekè, kad veiktų atskiros vokiečių parapijos ar filijos, kuriose pamaldos būtų vedamos tik vokiečių kalba. Šis vokiečių evangelikų liuteronų reikalavimas nesikeitė per visą tarpukarị. 1938 m. sausio mèn. Kaune pirmą kartą po ketverių metų pertraukos ịvykusiame Lietuvos vokiečiu evangelikų liuteronų Bažnyčios sinode jo pirmininkas P. Titelbachas, apžvelgęs vokiečių evangelikų liuteronų Bažnyčios padètį, išreiškẻ susirūpinimą dèl vokiečių kalbos vartojimo pamaldose ir tikybos pamokose. Esą nesuprantamas dalykas, kad, pavyzdžiui, katalikai reikalauja ịvesti lietuvių kalbą evangelikų liuteronų bažnyčiose, laikyti pamaldas lietuviškai. Šių konfesijų sekejjai daugiausia esą vokiečiai. Lietuvių ir latvių jei ir pasitaiką, tai ne tiek daug. Vokiečiai esą nusistatę prašyti, kad jiems būtų leidžiama kurti vokiškas liuteronų evangelikų parapijas. Mat mišriose parapijose esą neįmanoma suderinti skirtingų kalbų reikalų. Vokiečiams trūksta Lietuvoje pastorių ir kantorių. Kai kada jų pareigų imasi į pensiją išèję mokytojai arba muitinių valdininkai18.

Nepavykstant gauti leidimo steigti tik vokiškas liuteronų evangelikų parapijas, laikantis nuostatos, jog Lietuvoje vokiečiai evangelikai liuteronai yra skriaudžiami, vokiečiu evangelikų liuteronų vadovybè tuo klausimu raše įvairaus pobūdžio raštus konsistorijai ar Lietuvos valdžios atstovams. Būdingame Lietuvos vokiečių evangelikų liuteronų sinodo valdybos $1935 \mathrm{~m}$. balandžio $6 \mathrm{~d}$. pranešime švietimo ministrui buvo teigiama: 
Pagrindinis mūsų reikalavimas bažnyčios labui, yra: išskirti bendrąsias tautinio
arba kalbos atžvilgiu mišrias parapijas ir sudaryti iš jų savistovias tautines
arba kalbines parapijas. Kiekvienai, šių parapijų leisti laisvai pasirinkti arba
aptarnavimui pasikviesti pageidaujamą kunigą. <...>. Dabar beveik visose pa-
rapijose lietuviai, vokiečiai, latviai renka atskirai parapijos tarybas. Iš išrinktų
atstovu Konsistorijos nurodymu sudaroma bendra taryba $<\ldots>$. Turint galvoje
evangelikų liuteronų bažnyčios savitumus, tenka pažymeti, kad kol bus bendros
parapijos ir bendros tarybos, tol neramumai ir nesusipratimai nesibaigs. <...
Jei vokiečiams būtų leista sudaryti savo atskiras parapijas ir lietuviai sudaryti
savąsias, tada gal atsirastų nuolat prikišamas kaltinimas, jog per bažnyčią va-
roma germanizacija. ${ }^{19}$

Pareiškẻjų nuomone, Suvalkijos lietuvių evangelikų (Marijampolès, Vilkaviškio, Virbalio ir kt.) nusiskundimai esą nesuprantami: „Vietoje, kad atskirti nuo vokiečių, suorganizuoti savo parapijas, išsirinkti savo atskiras tarybas, pasikviesti sau kunigą lietuvị, jie įeina ị bendrąsias tarybas, kuriose sudaro mažumą. Čia kyla nuomonių skirtumai, pasèkoje nesusipratimai ir vèliau skundai per spaudą ir Ministerijai, kad lietuviai evangelikai slopinami. “20 1939 m. kovo 7 d. vokiečių sinodo senjoras P. Titelbachas Evangeliku liuteronų konsistorijai adresuotame rašte, priminęs, kad jo ligšiolinès pastangos nedavė rezultatų, o „dabartinė padètis pasidarè nepakenčiama“, pakartotinai išreiškè savo reikalavimus ir prašè juos perduoti Švietimo ministerijai. Rašte buvo sakoma:

1. Vokiečių Sinodo Senjoras turi teisę savo nuožiūra vieną kartą metuose sušaukti vokiečiu sinodą, o reikalui esant, pakviesti atstovus nepaprastam sinodui.

2. Vokiečių sinodo nutarimai yra privalomi vokiečių parapijoms.

3. Prie vokiečių parapijų priklauso visi, evangelikai liuteronai, kurie pargeidauja pamaldų vokiečių kalboje.

4. Vokiečių parapijoms vadovauja vokiečių senjoras.

5. Vokiečių vaikai mokyklose ir konfirmacijos pamokose, tėvams pageidaujant, turi būti mokomi vokiečių kalba.

6. Tautybės pažymėjimą duoda vietos pastorius arba senjoras. Šitas pažymėjimas privalo visose mokyklose ir visų tikybų mokytojų būti pripažintas.

7. Visur ten, kur tikybos pamokos laikomos ne vokiečių kalba, vokiečių vaikai privalo būti atleisti nuo tokių pamokų lankymo. Jie turi teisę mokytis privatiškai pas asmenis, kurie turi vokiečių senjoro leidimą. Mokyklos vadyba privalo pripažinti egzaminų davinius, kurie vietos pastoriaus paliudyti.

8. Evangelikų tikybos mokymas mokyklose, liečiantis vokiečių vaikus, privalo būti vokiečių senjoro priežiūroje.

9. Mokyklose, kuriose tikyba mokoma vokiečių kalboje, egzaminai privalo būti laikinomi vokiečių kalba. ${ }^{21}$

P. Titelbacho teigimu, „aukščiau išdèstyti reikalavimai yra minimumas evangeliku bažnyčios nenormaliai padèčiai pataisyti ${ }^{\text {“22. }}$. Viltasi, jog Konsistorija dès pastangas šiuos reikalavimus patenkinti ${ }^{23}$. 
Tačiau Evangelikų liuteronų konsistorijai atrodė, kad „yra nepageidautina visas parapijas skaldyti tautiškomis parapijomis, nes tokios tvarkos negalima išvesti iš Šv. Rašto ir iš esamų faktinių sąlygų "24, todèl vokiečių sinodo siūlymas sudaryti atskiras vokiečių parapijas ir įsteigti atskirą vokiečių skyrių konsistorijoje nepriimtinas. Konsistorija baiminosi, kad vokiškose evangelikų liuteronų parapijose bus vykdomas vokietinimas ir šio proceso nebus galima sukontroliuoti. Kad tokie būgštavimai turèjo realaus pagrindo, iliustruoja Lietuvos valdžios, kuri mokejjo atlyginimus dvasininkams už jų atliekamą darbą ${ }^{25}$, surinkta gausi dokumentinè medžiaga apie atskirų vokiečių tautybès evangelikų liuteronų dvasininkų veiklą savo parapijose, biografinès žinios apie tų dvasininkų ideologines ar politines pažiūras. 1927 m. pradžioje greičiausiai tikybų reikalų referento Augustino Vaitiekaičio pranešime vidaus reikalų ministrui pažymèta, jog $1919 \mathrm{~m}$. spalio $15 \mathrm{~d}$. tarpininkaujant Tikybų departamentui buvo sušauktas sinodas. $1920 \mathrm{~m}$. sausio $20 \mathrm{~d}$. vidaus reikalų ministras patvirtino laikinąją konsistoriją. $1922 \mathrm{~m}$. balandžio $1 \mathrm{~d}$. trejiems metams patvirtinta nuolatine konsistorija su prezidentu pastoriumi Martinu Kibelka priešakyje (prokuroru paskirtas Oskaras Büchleris). Minėtame pranešime M. Kibelkos vadovaujama konsistorija ìvertinta neigiamai. Nurodyta, jog 1922 m. liepos 20 d. konsistorija nusiuntė vidaus reikalų ministrui savo Bažnyčios įstatymo projektą, su kuriuo susipažinęs Ministrų Kabinetas grąžino ji atgal. Sinode konsistorijos prokuroras vokiečių tautybès O. Büchleris, „motyvuodamas pastorių vedamą valstybei kenksmingą politiką, pragrasino visiems kalejimu. Dar okupacijos metu [turima omenyje Vokietijos okupacija Lietuvoje 1915-1918 m. - aut. past.], buv. Vokiečių valdžios, iš Vokietijos pakviesta Lietuvon keletas misionierių. P. Kibelka būdamas prezidentu, parsikvietè iš Vokietijos misionierių Ekertą ${ }^{26}$ ir apgaulingu keliu išgavo iš Vid. Reik. M-rio leidimą būti pastorium Garliavoje.

Kiti misionieriai atsirado Lietuvoje, daugiausiai p. Kibelkos laikais, gaudami leidimą ìvažiuoti kaipo paprasti piliečiai. Vèliau konsistorija juos paskyrẻ klebonais.

Tuo tarpu einant bažnyčios įstatymais /XI t. 1, d. 402 str./ svetimšaliai pastoriai turi gauti specialų M-rio leidimą būti pastorium Lietuvoje.

Taipogi nuo kandidatų i pastorius reikalaujamas aukštojo mokslo diplomas. /Svetimšalių pastorių neturinčių leidimo yra 8. Neturinčių Universiteto diplomo visi, išskyrus $-5 . /<\ldots>$. p. Kibelka, per visą savo Konsistorijos prezidentavimo laiką, nesiskaitè su Vid. Reik. M-jos ir įstatymų reikalavimais /pav. Ekerto, Vyšeropo ir kitų pastorių bylos ${ }^{27} /$. Metrikai, visose parapijose, buvo rašomo vokiečių kalba, antrieji egz.[emplioriai] nebuvo siunčiami Konsistorijon, oficialiuose raštuose buvo vartojama ir gi vokiečių kalba. Vokietinimo politika buvo vedama per bažnyčią visu frontu. Net rinkimuose ị Seimą, buvo p. Kibelkos pasiųstas aplinkraštis pastoriams, liepęs evangelikams-liuteronams balsuoti tik už vokiečių sąrašus. Pastoriai gaudami lèšas iš svetimos valstybès [turima omenyje Vokietija - M. T. past.], patys būdami daugiausiai ne Lietuvos piliečiai ir jei svetimos dvasios, dirbo ir dirba ne tikybos labui, bet svetimos valstybès naudai“ ${ }^{28}$. Kaip nurodyta pareiškime, „tokia padètis buvo nepakenčiama“29. Tad pasibaigus M. Kibelkos konsistorijos darbo kadencijai, 1925 m. vasarą lietuvių, latvių ir vokiečių sinodų suvažiavimai išrinko savo kandidatus į naują konsistoriją. Tada daug ginčų kilo dèl naujo konsistorijos prezidento prof. V. Gaigalaičio išrinkimo. Tik pradejus dirbti naujai konsistorijai iš jos 
pasitraukè du vokiečiai ir vienas latvis; liko dirbti du lietuviai, vienas latvis ir prokuroras. Juridiškai konsistorijos veikla buvo teisèta ir ji atstovavo visai šalies Evangelikų Liuteronų Bažnyčiai. Pasitraukusių atstovų vietos buvo vakuojamos ir jie bet kada galejo grịžti ị konsistoriją. Tuo tarpu Lietuvos valdžia neprièmè prof. V. Gaigalaičio atsistatydinimo, o pasitraukusieji vokiečiai su P. Titelbachu priešakyje griežtai atsisakè „eiti i bet kurias derybas“30. Turèdamas tai omenyje tikybos reikalų referentas padare šią išvadą: „Ev.-liuter. bažnyčią niekas nepersekioja, bet vokiečiai pastoriai, negalèdami sutikti su tautiniai nusistačiusiais lietuviais, konsistorijos nariais /teisètais išrinktais/ kurių rinkimas šių metų lietuvių sinodas vienbalsiai patvirtino ir jų veikimą užgynė, nenori kartu dirbti. Pasinaudodami svetimais pinigais leidžiamuose kaip Lietuvos kaip ir užsienio vokiečių laikraščiuose šmeižia Lietuvos valstybę." ${ }^{31}$

Vokietinimas ypač aktyviai vykdytas pasienio ruože su Vokietija. Kaip matyti iš 3 lentelès, šioje teritorijoje, o kartu tose vietovėse, kur buvo susitelkusi vokiečių bendruomenė, daugiausia dirbo vokiečių tautybès evangelikų liuteronų dvasininkai. Antai 1928 m. Vilkaviškio apskrities viršininko vidaus reikalų ministrui adresuotame raporte nurodyta, kad „germanizacijos tikslams yra naudojama evangelikų bažnyčia. Kiti ir nemokẻdami netgi vokiškai kalbèti sakosi sulig tikyba esą vokiečiai: „evangelikas“ yra sinonimas „,vokietys“. Išmokti ir kalbèti vokiškai tai yra kiekvieno tikinčio pareiga, taip tikina savo parapijonius vokiečiai pastoriai. Pastorių gi itaka žmonèms didelë“32. Kaip pavyzdys nurodyti rinkimų i Lietuvos III Seimą balsavimo rezultatai: vokiečių evangelikų sąrašas Gražiškių valsčiuje surinko 506 balsus, Vištyčio sąrašas - 337 balsus, o tose pačiose vietovèse lietuvių evangelikų sąrašas daugiausia gavo du balsus, tiesiog evangelikų - 12. Vilkaviškio apskrities viršininko nuomone, „užkirsti kelią germanizacijai būtinai reikalinga esamus pastorius pakeisti pastoriais tikrais lietuviais, mylinčiais savo kraštą ir kalbą, tik jie galètų išdildyti ilgais metais ịkaltą nuomonę „evangelikas“ tai jis ir - „vokietys“33. Raporto autorius germanizaciją vykdančius pastorius, negalint jų visai atleisti, siūlè iškelti bent ị vidurị Lietuvos ${ }^{34}$.

Tauragès Naumiesčio evangelikų liuteronų parapijos klebonas kun. Dovydas Jurkaitis, kurị Tauragès apskrities viršininkas įvardijo kaip „didelį germanofilą “35, stengèsi suvokietinti vietos gyventojus evangelikus: jis juos ịkalbinėjo savo vaikus leisti tik ị vokiečiu privačią mokyklą, atsisakyti savo tautiškumo ir imtis veiksmų, kad pasuose lietuvių tautybẻ būtų pakeista ị vokiečių. Panašiai elgèsi ir Meldikviršių privačios mokyklos vedèjas A. Rederis ir Tauragès evangelikų liuteronų parapijos klebonas kun. Augustas Vymeris. Jie abu dejjo daug pastangų, kad Tauragejje būtų ịkurta vokiečių mokykla. Kai nepavyko rasti reikiamo skaičiaus žmonių vokiečių tautybès, jie ịkalbinėjo žmones lietuvių tautybès savo pasuose lietuvių tautybę pakeisti į vokiečių tautybę ${ }^{36}$. Raseinių apsk., Jurbarko vlsč., Žvyriuose, evangelikų liuteronų bažnyčios kunigas vokietis $H$. Jèkelis tarp vietos evangelikų „varè vokietinimo darbą“"37. Evangelikus lietuvius stengèsi „užskaityti“ vokiečiais, kad turètų balsų daugumą ${ }^{38}$. Panašia veikla užsièmė Skuodo vokiečių evangelikų liuteronų kunigas, Latvijos pilietis Maksas Bordelis: „Nežiūrint administracijos ịspejjimų ir grasinimų jị išvyti iš Lietuvos vis tik jis nesiliauja varęs germanizavimo darbą. " ${ }^{\text {"39 }}$

Pasitaikydavo atvejų, kai vokiečių tautybès evangelikų liuteronų dvasininkai atsisakydavo vykdyti Lietuvos evangelikų liuteronų konsistorijos nutarimus (Jurbarke liuteronų evangelikų kunigą Julių Stanaitị konsistorija buvo suspendavusi, tai jis ịsteigè 
atskirą parapiją, vokiečių palaikomą, ir iš Jurbarko nesikèlè. I šị reikalą turèjo net ịsikišti komendantas ir J. Stanaitị iš Jurbarko ištremè ị kitą apskriț ${ }^{40}$; tačiau ištrèmus iš Jurbarko kunigą vokietị J. Stanaitị, parapijiečiai vokiečiai naujai paskirto kunigo H. Jèkelio neịsileido, nedave jam parapijos raktų ir reikalavo grąžinti ištremtąjj ${ }^{41}$ ) arba kai kurie evangelikų liuteronų dvasininkai nesugebẻdavo atsilaikyti prieš parapijiečių spaudimą ir imdavo palaikyti vokiečių, o ne lietuvių evangelikų liuteronų pusę (Kretingos evangelikų kun. Adomas Gelžinis, „lietuviško nusistatymo žmogus“, irgi pradejo vokiečiams nusileisti. Jo parapijiečiai pradejjo vesti pamaldas privačiuose namuose grynai vokiečių kalba. Nors tai nedaug kur daroma, bet keliose apylinkèse: Rūdaičių, Kiauleikių ir Gargždų, tai buvo kelis kartus padaryta ir net dalyvavo keletas vokiečių iš Klaipėdos krašto. Pats kun. Adomas Gelžinis visa tai laikè nesvarbiu ir sakè, kad tai nieko nekenkia ${ }^{42}$ ). O vokiečiams evangelikams nepriimtini asmenys tiesiog būdavo atleidžiami iš pareigų (Kalvarijoje vokiečiai evangelikai atleido iš kantoriaus pareigų vieną asmenį, kuris daug dirbo „Pagalbos“ organizacijoje, platino tos organizacijos laikraštị „Srovę“ ir nepritarè vokietinimo akcijai ${ }^{43}$ ). Atskirais atvejais tarp vokiečių ir lietuvių liuteronų santykiai būdavo sprendžiami panaudojus ir fizinę jègą (pavyzdžiui, 1934 m. lapkričio 30 d. Šakiuose keli vokiečiai panaudojo smurtą prieš vieną asmenị, nes jis priklausẻ „Pagalbos“ sąjungai ir buvo vadinamas vokiečių išdaviku $)^{44}$.

Nuo šių ìvykių nuošalyje neliko ir Kulturverbandas, kurio atstovai labai atsargiai ir neviešai ịkalbinėjo evangelikus liuteronus, kad šie savo vaikus leistų tik ị vokiečių mokyklas, nes esą valdžios išlaikomose mokyklose jie būsią sukatalikinti, ir, kad galètų kuo daugiau vokiečių mokyklų įsteigti, ikkalbinejo juos kreiptis ị administracijos įstaigas, kad jų pasuose lietuvių tautybẻ būtų pakeista ị vokiečių. Jeigu pasai vietoje nebūsią pakeisti, tai raginta kreiptis ị vidaus reikalų ministeriją ${ }^{45}$.

Tokie Kulturverbando veiksmai davė rezultatų, nes suagituoti žmonės, pavyzdžiui, Tauragès apskrityje, ėmė laikytis nuošaliai ir net šalintis nuo lietuvių kultūrinio darbo, nedalyvavo lietuvių švenčių iškilmèse, vaikus pagal galimybes mokè tik vokiečių mokyklose ir „tam vokiečių nacionalizmui pareikšti kai kurie yra net tvoras nudažę nacionaline spalva, pav. Naumiesty “46. Didesnis vokiečių organizuotumas pasireiškè Vilkaviškio, Šakių ir iš dalies Marijampolès apskričių tose vietose, kur gyveno daugiau evangelikų. Vokiečiai visus evangelikus gyventojus laikè savo žmonėmis ir stengėsi juos šiokiu ar kitokiu būdu patraukti ị savo pusę. Nors vietomis lietuviai evangelikai pradèjo reikalauti savo teisių, pavyzdžiui, Marijampolëje, tačiau tokių susipratusių lietuvių evangelikų dar buvo mažuma. Pavyzdžiui, Vilkaviškio apskrityje, Vištytyje ir apylinkejje, gausiau gyveno evangelikai, jie dar neorganizuoti. Evangelikai inteligentai laikèsi nuošaliai ir neprisidejo „prie stiprinimo akcijos lietuviškumo naudai evangelikų tarpe ${ }^{\text {“477. }}$.

Reikètų pridurti, kad vokiečių tautybės evangelikų liuteronų kunigus gynė vokiečių evangelikų liuteronų sinodo, o kartu ir Kultuverbando (1935 m. prie Kulturverbando buvo prijungtos visos vietos vokiečių evangelikų draugijos ${ }^{48}$ ) vadovybès. Jos buvo tarpusavyje glaudžiau susijusios, nes kai kurie asmenys, kaip P. Titelbachas ${ }^{49}$, skyręs daug dèmesio vokiečių reikalams ginti, vienu metu užèmè vadovaujamas pareigas abiejose organizacijose. Todèl šalia vokiečių evangelikų liuteronų sinodo analogiškus raštus, ginančius vietos vokiečius, rašè ir Kulturverbandas. 
Aktyviai veikiant vokiečiams evangelikams liuteronams, lietuviai evangelikai liuteronai sąmonèjo ir turẻdami šalies valdžios paramą mėgino išsikovoti sau daugiau teisių. Svarbus vaidmuo teko lietuvių evangelikų liuteronų 1923 m. įsteigtai sąjungai „Pagalba“ (Taurageje ją įsteigė jauni, patriotiškai nusiteikę liuteronai inteligentai: Mikas Preikšaitis, Mikas Jonušaitis, Andrius Gintautas ir Kristupas Gudaitis). „Pagalba“ siekė: 1) pagyvinti parapijų veiklą puoselëjant švietimą ir tautini susipratimą; 2) skatinti parapijiečius aktyviai veikti, kad atsvertų vokiečių ịtaką; 3) apskritai stiprinti lietuvių protestantų vardą bei prestižą lietuvių visuomenej $\mathrm{e}^{50}$. Minèta sąjunga taip pat buvo už bendravimą ir bendradarbiavimą su Klaipėdos kraštu, 1923 m. prijungtu prie Lietuvos. Todèl „Pagalbai“ atrodè priimtinas lietuviško nusistatymo tuometinis Klaipẻdos krašto mokyklų decernentas ir pasižymėjęs mažlietuvių veikèjas dr. kun. V. Gaigalaitis. 1924 m. jis kandidatavo Sudargo sinode, 1925 m. buvo išrinktas ir Lietuvos vyriausybės patvirtintas Evangelikų liuteronų konsistorijos prezidentu (šias pareigas jis èjo beveik dešimtmetị) ${ }^{51}$.

Lietuvių evangelikų organizacija „Pagalba“ nuo $1931 \mathrm{~m}$. pabaigos pradejo leisti dvisavaitinị laikraštị „Srove““ (ejo iki 1935 m.). Leidinio redakcija jau pirmajame leidinio numeryje pažymèjo:

Laikraštị leisti iššaukè gyviausi mūsų, lietuvių evangelikų, reikalai. Pagaliau, jau laikas, kad ir evangelikas lietuvis tartų žodị per savo spaudą. <...>. Tiesa, šiuo metu leidžiamas vokiečių kalba laikraštis, bet jis savo kaikuriais straipsniais ne nesuartina Lietuvos evangelikus, bet juos sukiršina. Tokiems kiršinimams mes norime kelią pastoti. Apie evangelikus skleidžiamos žinios dažniausiai, lenkiasi su tiesa. Gana tylèti! Mes norime evangelikams be tautybès skirtumo patarnauti teisingomis žiniomis, naudingais patarimais bei straipsniais. Mes kalbèsime pirmoj eilèj apie tikybos ir bažnyčios dalykus, bet taip pat neužmiršime kultūrinių ir tautinių klausimų. Todèl pasireiškia nauja srové mūsų gyvenime. Šita srovė tegul išplauna visus nesusipratimus ir neapykantą iš evangelikų tarpo. Gal kai kam su mūsų "Srove“ ir nebus pakeliui, tačiau, kam rūpi mūsų tikejjimo dalykai, bažnyčios gerové, mūsų kultūrinis augimas, evangelikų vienybẻ ir Tẻvynès meilè, kviečiame it talką. ${ }^{52}$

Tačiau peržvelgus „Srovès“ numerius galima susidaryti prieštaringą vaizdą: laikraštyje iš tiesų daug dèmesio skirta lietuvių evangelikų reikalams (pateikiamos išsamios žinios apie atskiras šalies parapijas, kunigų veiklą ir pan.), bet kartu aštriai pasisakyta prieš vokiečius evangelikus liuteronus, ypač prieš jų vokiečių kalba leistą laikraštị „Deutsche Nachrichten“. Jau pirmajame „Srovès“ numeryje neigiamai įvertinas minètas vokiečių periodinis leidinys: „Kaune eina vokiečių savaitraštis „Deutsche Nachrichten“. Mes niekam nieko nepavydim, ypač, kol šis laikraštukas Lietuvos žmonėms nieko nekainuoja. Tačiau, ta aplinkybè, kad šiam laikraščiui bendradarbiauja žmonès, kurie Lietuvos valstybės organų šmeižimu seniai yra pasižymejję, jau iš anksto rodo šio laikraščio kryptị ir tikslą. “53 „Yra žinomas mūsų posakis: „Kas tavo, tas ir mano, bet kas mano, tas ne tavo“. Panašiai galvoja ir „Deutsche Nachrichten“: „Jeigu mes valdome ev. bažnyčią, jūs turite mūsų klausyti, jeigu jūs valdote - mes neklausysime. Mes nepolitikuojame - jūs politikuojate“. Čia kaipo „jūs“ figūruoja ne tik lietuviai, bet ir visi kiti evangelikai, kurie nèra 
vokiečių šalininkai. “54 Panašių straipsnių gausu „Srovèje“. Jos bendradarbiai pernelyg sureikšmino lietuvius, o drauge skelbẻ pirmiausia religinę neapykantą kitataučiams:

Svetimtautis savo galvojimu, savo būdu ir papročiais bei siekimais yra svetimas kitos tautos žmonèms, ir jo darbas nevertesnis už samdininko. <... . Kol atèjūnai, nesuprasdami mūsų siekimų ir mūsų dvasios, rodys mums kelią ir bus mūsų parapijose dvasiniais vadais, skelbs nesantaikos dvasią, - tol mūsų dvasinio gyvenimo kelias bus vingiuotas, kalnuotas, ir mes juo eidami nepasieksime vienybės, nesukursime dvasinių nepragaištančių vertybių. ${ }^{55}$

„Srovejje“ skelbiamų straipsnių tonas, ị pirmą vietą iškeliant lietuviškumą ir vokietinimo smerkimą, radikalejjo, todèl Vokietijoje valdžioje issitvirtinus Adolfui Hitleriui ir pablogejjus Lietuvos ir Vokietijos santykiams, 4-ojo dešimtmečio viduryje Lietuvos valdžios nutarimu, „siekiant sušvelninti antivokiškas tendencijas lietuvių liuteronų bažnyčioje “56, organizacija „Pagalba“ buvo uždrausta, o „Srovès“ leidyba nutraukta.

Nepaisant ryžtingų Lietuvos veiksmų prieš „Pagalbą“" ir „Srovę“, 4-ajame dešimtmetyje lietuviai evangelikai, pirmiausia tose parapijose ar filijose, kur lietuviai sudarė daugumą arba buvo pasiskirstę tolygiai su vokiečiais, pradejo reikalauti, kad parapijose pamaldos vyktų lietuvių kalba. Viename Marijampolès parapijos lietuvių evangelikų prašyme, adresuotame Marijampolès evangelikų liuteronų parapijos klebonui, rašyta:

1. Sekmadieniais lietuvių kalba laikomų pamaldų skaičių sulyginti su skaičiumi pamaldų laikomų vokiečių kalba, atliekant jas pakaitomis. 2. Atlaikyti lietuviškas pamaldas per tautines lietuvių šventes kada jos laikomos ir kitų tikybų bažnyčiose. 3. Nelaikyti lietuviams evangelikams pamaldų per šventes, kada švenčiamos vien katalikų. Jei yra reikalas /būtinas/ laikyti pamaldas ir ne evangeliku švenčiamomis dienomis, tai laikyti ne vien tiktai lietuviams, bet lygiai tiek pat kartų ir vokiečiams. ${ }^{57}$

Panašaus pobūdžio prašymų-reikalavimų gausu. Jie tik liudija, kad pamažu augo pačių lietuvių evangelikų liuteronų sąmoningumas ir siekta savo parapijose išsikovoti bent jau vienodų teisių su vokiečiais evangelikais liuteronais. Kadangi Evangelikų liuteronų konsistorija nuo V. Gaigalaičio vadovavimo laikų rèmé lietuvių evangelikų liuteronų siekius, lietuvių evangelikų liuteronų pastangos nenuejo veltui. Sostinejje, kur evangelikų liuteronų bažnyčioje pamaldos iki 1930 m. vyko tik vokiečių kalba ${ }^{58}, 1931$ m. pradžioje Lietuvos evangelikų liuteronų konsistorijos nutarimu priimtas sprendimas, pagal kurị Kaune, kaip ir visose kitose vietose, veiktų viena evangelikų liuteronų parapija, kuriai turejo priklausyti ir lietuviai (pastariesiems nutarta skirti atskirą kunigą ${ }^{59}$ ). Dar po kelerių metų Kaune lietuviai evangelikai liuteronai igijo teisę klausytis pamaldų lietuvių kalba ${ }^{60}$. Nors sostinejje ịtampa tarp lietuvių ir vokiečių evangelikų liuteronų dar kurị laiką išliko (Kauno parapijos tarybos nariai vokiečiai nenorèjo sutikti posèdžiauti kartu su tarybos nariais lietuviais) ${ }^{61}$, 4-ojo dešimtmečio viduryje vokiečiai prarado turètą monopolinę ittaką Kauno evangelikų liuteronų bažnyčioje ${ }^{62}$. Tuo metu jau daugumoje evangelikų liuteronų parapijų pamaldos buvo laikomos paeiliui: vieną kartą lietuvių kalba, kitą kartą vokiečių ${ }^{63}$. Pamažu santykiai tarp vokiečių ir lietuvių evangelikų liuteronų stabilizavosi ir tokia padètis išsilaikè iki Lietuvos okupacijos. 


\section{Išvados}

1. Pirmuoju nepriklausomybès dešimtmečiu vokiečių vyravimą Lietuvos evangelikų bendruomenejje lèmé šios tautybès atstovų nuo senų laikų užimtos vadovaujamosios pareigos šalies Evangelikų Liuteronų Bažnyčioje, evangelikų liuteronų dvasininkų turètas monopolis skelbiant tikejjimą tikintiesiems (nepriklausomybès pradžioje beveik nebuvo lietuvių tautybės liuteronų kunigų), vokiečių bendruomenès kiekybinis pranašumas (1923 m. vokiečiai sudarè 43,06 proc., lietuviai - 33,51 proc., latviai - 20,36 proc. visų evangeliku liuteronų, likusią nedidelę evangelikų liuteronų dali sudarè kitos tautos ir svetimšaliai).

2. XX a. 4-ajame dešimtmetyje Lietuvos evangelikų liuteronų bendruomenèje vokiečiai prarado vadovaujamąsias pozicijas. Tam ịtakos turejo Lietuvos evangelikų konsistorijos vadovybės griežta pozicija kovojant prieš vokietinimą tarp evangelikų liuteronų, lietuvių evangelikų liuteronų kunigų gausẻjimas, pačių lietuvių tautybės liuteronų sąmonejjimas kovojant su vokiečių tautybès evangelikais liuteronais už savo lygias teises ir vadovavimą minètai religinei bendruomenei.

\section{NUORODOS}

1 Hermann A. Lietuvių ir vokiečių kaimynystè. Vilnius: Baltos lankos. 2000. P. 95-153, 189-211; Hermann A. Lietuvos evangelikų liuteronų bažnyčia 1915-1995 m. // Lietuvos evangelikų bažnyčios: istorijos metmenys (sud. A. Hermann). Vilnius: Baltos lankos. 1993. P. 221-276.

2 Slavéniené M. G. Evangelikų teologijos fakultetas Kaune 1925-1936 m. // Lietuvos evangelikų bažnyčios. Ten pat. P. 399-416.

3 Puidokiené I. Vokiečių tautinė mažuma Lietuvos Respublikoje 1918-1940 m. (Be Klaipėdos krašto). Magistro baigiamasis darbas. Kaunas: Vytauto Didžiojo universiteto leidykla. 2009. vddb.library. lt/fedora/get/LT-eLABa-0001:E.02 2009 D_20090813_093356-58392/DS.005.0.02.ETD. Žiūrèta 2013-06-20. Sutrumpintas autorès magistro darbas perspausdintas Vokietijoje: Puidokiené I. Die deutsche Minderheit in Litauen 1918-1940 (ohne das Memelgebiet) // Annaberger Annalen. 19/2011. S. 29-67.

4 Puidokienè I. Kauno evangelikų liuteronų bažnyčios vidaus konfliktas 1918-1940 m. // Kauno istorijos metraštis. Kaunas: Vytauto Didžiojo universiteto leidykla. 2009. T. 10. P. 59-72; Puidokiené J. Kauno evangelikų liuteronų parapija 1919-1953 m. // SOTER. Kaunas: Vytauto Didžiojo universiteto leidykla. 2013. Nr. 46 (74). P. 69-82.

5 Tautybių konfesinè sudètis $1923 \mathrm{~m}$. rugsèjo $17 \mathrm{~d}$. gyventojų surašymo duomenimis \% // http:// gevask.dtiltas.lt/LS1919/HTM/a059.html. Žiūrèta 2013-07-18.

6 Lietuvos gyventojų konfesinè sudètis $1923 \mathrm{~m}$. rugsèjo 17 d. gyventojų surašymo duomenimis // http://gevask.dtiltas.lt/LS1919/HTM/a057.html. Žiūrèta 2013-07-18.

7 Lietuvos gyventojų konfesinė sudètis tautybėmis $1923 \mathrm{~m}$. rugsèjo $17 \mathrm{~d}$. gyventojų surašymo duomenimis \% // http://gevask.dtiltas.lt/LS1919/HTM/a058.html. Žiūrèta 2013-07-18.

8 Hermann. Lietuvių ir vokiečių kaimynystè. Ten pat. P. 100.

9 1919-1927 m. beveik visi liuteronų kunigai neturèjo Lietuvos pilietybės. Ginčai tarp vokiečių sinodo, atskirų grupuočių ir konsistorijos dèl dvasininkų (dalis jų buvo priversti išvykti, dalis pasitraukè opozicijon, atsikèlèliai nuo vokiečių sinodo, atrodo, bandè dargi kurti savarankišką vokiečių Bažnyčią) 3-iojo dešimtmečio pabaigoje pradejjo silpti - „po $1930 \mathrm{~m}$. vokiečiai apsiprato su mažumos sąlygomis ir prièmė lietuvių viršenybę bažnyčioje“. (Ten pat. P. 205).

10 Konsistorijos reikalų vedèjas. Lietuvos Evang. Liut. Konsistorijos žinioje esančių dvasininkų sąrašas // LCVA. F. 391. Ap. 4. B. 760. L. 89-89AV. 
11 Universiteto pavadinimas nenurodytas; 1892-1896 m. V. Gaigalaitis studijavo Karaliaučiaus ir Berlyno universitetuose teologiją ir filosofiją; nuo $1900 \mathrm{~m}$. - evangelikų liuteronų kunigas [M. T. past.].

12 Valstybès saugumo ir kriminalinès policijos Šiaulių apygardos $1934 \mathrm{~m}$. birželio mėn. santrauka Nr. 16, 19340709 // LCVA. F. 378. Ap. 3. B. 3475. L. 339.

13 Slaveniené. Evangelikų teologijos fakultetas Kaune 1925-1936 m. Ten pat. P. 413.

14 Memorandumas Evangelikų Teologijos fakulteto likimo reikalu 19280725 // LCVA. F. 1778. Ap. 1. B. 9. L. 59-60.

15 Ten pat.

16 Lietuvos evangelikų liuteronų konsistorijos 19350406 pranešimas Švietimo ministerijai // LCVA. F. 391. Ap. 4. B. 631. L. 109.

17 Lietuva. Lietuvių enciklopedija. Vilnius: Lietuvos enciklopedijų redakcija. 1990. T. 15. P. 177.

18 Valstybès saugumo departamento Spaudos dienynas nr. 19, 19380125 // LCVA. F. 394. Ap. 6. B. 151. L. 55.

19 Lietuvos vokiečių evangelikų liuteronų sinodo valdybos pranešimas Švietimo ministrui 193504 06 // LCVA. F. 391. Ap. 4. B. 631. L. 303-304.

20 Ten pat.

21 Vokiečių sinodo senjoro P. Titelbacho raštas Evangelikų liuteronų konsistorijai 19390307 // LCVA. F. 391. Ap. 4. B. 1844. L. 135.

22 Ten pat.

23 Ten pat.

24 Pvz., 1928-1935 m. evangelikų liuteronų dvasininkų algoms išmokèti 473487 litai 43 centai (Švietimo ministerijos raštas Vidaus informacijos skyriui [1936 m.] // LCVA. F. 391. Ap. 4. B. 89. L. 58).

25 Ten pat.

26 Tikybos reikalų referento teigimu, Konsistorijos teismas savo posèdyje $1926 \mathrm{~m}$. balandžio 19 d. konstatavo, kad Ekertas konsistorijos nebuvo ir nèra paskirtas Garliavos pastoriumi ir konsistorija, pildydama Vidaus reikalų ministerijos reikalavimą, vietoj atleisto Ekerto administratoriumi paskyrè V. Gaigalaitị. Tačiau Ekertas atsisakė perduoti bažnyčią. Tik mirus Kybartų pastoriui, Ekertas savavališkai persikèlè ị Kybartus ir ten pradejo eiti pastoriaus pareigas. Tuo tarpu Vidaus reikalų ministerija nepratęsė jam leidimo gyventi Lietuvoje („jis kaipo svetimšalis nesiskaito su Lietuvos įstatymais ir nepildo svetimšaliams nustatytų nuostatų“). Tik įsikišus Vokietijos pasiuntinybei susitariama Ekertui pratęsti leidimą 6 mèn. kaip piliečiui. Bet „jei jis kesintųsi eiti kokias nors pastoriaus pareigas tč tuojau paprašyti atleisti Lietuvą" (Tikybos reikalų referento K. A. Vaitiekaičio pranešimas Vidaus reikalų ministrui [1927 m. pradžia] // LCVA. F. 391. Ap. 4. B. 68. L. 24).

27 P. Kibelkos vadovaujama konsistorija dejo daug pastangų, kad būtų atleistas Tauragès parapijos evangelikų liuteronų kunigas Augustas Vymeris. Anot tikybos reikalų referento, „p. Kibelkos Konsistorija su visu įnirtimu puolè past. Vymerị dẻl to, kad jis pildè teisètus lietuvių-vokiečių reikalavimus ir nesutinka dirbti kartu su kitais pastoriais Deutschland'o naudai“ (Ten pat. P. 25).

28 Tikybos reikalų referento K. A. Vaitiekaičio pranešimas Vidaus reikalų ministrui [1927 m. pradžia] // LCVA. F. 391. Ap. 4. B. 68. L. 20-21.

29 Ten pat.

30 Ten pat. L. $21-22$.

31 Ten pat. L. 21-22.

32 Vilkaviškio apskrities viršininko raportas Vidaus reikalų ministrui 19280224 // LCVA. F. 394. Ap. 2. B. 840. L. 85.

33 Vilkaviškio apskrities viršininko raportas Vidaus reikalų ministrui 19280224 // LCVA. F. 394. Ap. 2. B. 840 . L. 85.

34 Ten pat.

35 „Jurkaitis yra didelis germanofilas, kaipo toksai dirba lietuvių nenaudai ir varo vokietinimo darbą. Jurkaitis savo parapijiečių tarpe skleidžia ịvairius nepamatuotus gandus, kurie kiršina vietos 
gyventojus, sukelia jų tarpe neramumų, abejonę ir nepasitenkinimą. Taip pat jis varo smarkią akciją prieš savo tiesioginę vyriausybę - Lietuvos evang. liut. konsistoriją. Jurkaitis savo parapijonų tarpe skleidžia gandus esą konsistorijos pirmininkas d-ras Gaigalaitis padaręs su Katalikų dvasiškija sutartị sukatalikinti Lietuvos evang. liuteronus. Vaikščiodamas po žmones Jurkaitis tèvus prikalba neleisti savo vaikų ị lietuviškas mokyklas, bet leisti į vokiškąsias.

Tokiomis savo kalbomis Jurkaitis yra parapiją suskaldęs ị 2 dalis, kurios tarp savęs nesutinka. Savo tokiu elgesiu jis savo parapijonų tarpe skiepija neapykantą ir todèl tenka konstatuoti jo šalininkų tarpe didèjantị [didejjančią - aut. past.] antipatiją lietuvių tautai ir valstybei“ (Tauragès apskrities viršininko raportas Vidaus reikalų ministrui Piliečių apsaugos departamento direktoriui $19290801 / /$ LCVA. F. 394. Ap. 4. B. 182. L. 6).

36 Tauragès apskrities viršininko raportas Vidaus reikalų ministrui Piliečių apsaugos departamento direktoriui 19310202 // LCVA. F. 394. Ap. 2. B. 868. L. 288.

37 Valstybès saugumo ir kriminalinès policijos Šiaulių apygardos $1934 \mathrm{~m}$. balandžio mèn. žinių santrauka // LCVA. F. 378. Ap. 3. B. 3475. L. 447.

38 Ten pat.

39 Valstybès saugumo ir kriminalinès policijos I rajono biuletenis nr. 8, Šiauliai. 19310110 // LCVA. F. 378. Ap. 3. B. 795. L. 191.

40 Valstybès saugumo ir kriminalinès policijos Šiaulių apygardos $1934 \mathrm{~m}$. gegužès mèn. žinių santrauka // LCVA. F. 378. Ap. 3. B. 3475. L. 392-393.

41 Valstybès saugumo ir kriminalinès policijos Šiaulių apygardos $1934 \mathrm{~m}$. birželio mèn. santrauka Nr. 16, 19340709 // LCVA. F. 378. Ap. 3. B. 3475. L. 339.

42 Valstybès saugumo ir kriminalinès policijos Šiaulių apygardos $1934 \mathrm{~m}$. gegužès mèn. žinių santrauka // LCVA. F. 378. Ap. 3. B. 3475. L. 392-393.

43 Valstybès saugumo ir kriminalinès policijos Marijampolès apygardos $1934 \mathrm{~m}$. vasario mèn. žinių santrauka // LCVA. F. 378. Ap. 3. B. 3475. L. 601.

44 Valstybès saugumo ir kriminalinès policijos Marijampolès apygardos $1934 \mathrm{~m}$. lapkričio mèn. žinių santrauka // LCVA. F. 378. Ap. 3. B. 3475. L. 100.

45 Tauragès apskrities viršininko pranešimas Piliečių apsaugos departamento direktoriui 19310502 // LCVA. F. 394. Ap. 2. B. 868. L. 99.

46 Ten pat.

47 Valstybès saugumo ir kriminalinès policijos Marijampolès apygardos $1934 \mathrm{~m}$. kovo mèn. žinių santrauka // LCVA. F. 378. Ap. 3. B. 3475. L. 530.

48 Jakubavičiené I. Moterų vaidmuo Lietuvos vokiečių organizacijų veikloje XX a. 3-4 dešimtmečiuose // Lyčių studijos ir tyrimai. Šiauliai: Šiaulių universiteto leidykla. 2009. Nr. 7. P. 49.

491939 m. vasarą VSD vadovybè slaptame rašte Spaudos ir draugijų skyriaus vedèjui apie liuteronų parapijos kleboną Povilą Titelbachą rašè: „Povilas Titelbachas, gimęs $1865 \mathrm{~m}$. Bauske, visą laiką gyvena Kèdainių valsčiuje, kur turi 93,83 ha žemés ūkị. Jis yra nacionalsocializmo šalininkas ir visada pasireiškè kaip aktyvus vokietis. Nuo pat Kulturverbando skyriaus įsteigimo buvo nuolat renkamas valdybos nariu, o dabar yra tos organizacijos centro garbès narys. Jo pastangomis Kèdainiuose įsteigta vokiečiu pradžios mokykla, kuriai jis išrūpino iš parapijos veltui namus ir apšildymą. Toje mokykloje šiais metais mokèsi 14 vaikų, surinktų iš ịvairių apskrities vietų.

Nuo $1938 \mathrm{~m}$. Titelbacho ūkyje buvo pradètos rengti iškylos, kuriose skiepijamas nacionalsocialistinis auklejjimas. Iškylauti buvo stengiamasi sutraukti visi tie, kurie yra evangelikų liuteronų tikybos, nežiūrint jų lietuviškos kilmès. Titelbachas iškylautojams veltui duoda patalpas, padaro įrengimus, leidžia naudotis susisiekimo priemonèmis ir programai Ł̨vykdyti nesigaili žemės. Iškylautojai tvarkosi kariškai, nes būna paskirti viršininkai, naktinè apsauga, maisto tiekejjai ir gamintojai. Turtingesnieji už dienos maistą moka po $1 \mathrm{Lt}$, o už neturtinguosius sumoka Kulturverbando centro valdyba.

1938 m. birželio 19-25 d. Titelbacho ūkyje iškylavo 43 Kauno vokiečių gimnazijos mokiniai ir 3 studentai, o rugpjūčio 12-22 d. buvo surengta vokiečių jaunuolių iškyla, kurioje dalyvavo 23 žmonés, surinkti iš ịvairių Lietuvos vietų. 
1939 m. birželio 20 d. iki liepos 7 d. iškylavo 37 vokiečių mergaitès, sukviestos iš viso krašto. Liepos 2 d. buvo atvykę iškylauti vokiečių vadai ir vaikų darželių vedèjai, kuriems turèjo ịvykti kursai. Kadangi neturèjo leidimo, tai suvažiavusiųjų 12 iškylautojų turèjo išsiskirstyti. Liepos 9 d. Kulturverbando centro valdyba norèjo surengti 40 vokiečių jaunuolių iškylą, kuri turèjo užtrukti net 3 savaites laiko. Tai iškylai taip pat nebuvo duodas leidimas, todèl susirinkusieji turèjo išsivažinèti“. Beje, Povilo Titelbacho sūnus Hansas Verneris Titelbachas gyveno ir tarnavo policijos valdininku Karaliaučiuje, kur užèmė aukštas pareigas nacionalsocialistų partijoje. Jis vasaros laikotarpiu atvažiuodavo pas tèvą ir čia susitikdavo su Lietuvos vokiečių jaunimo vadais. (Laikinai einančio VSD direktoriaus pareigas F. Bortkevičiaus raštas Spaudos ir draugijų skyriaus vedejui 19390724 // LCVA. F. 377. Ap. 10. B. 427. L. 41).

50 Slaveniené G. Evangelikai liuteronai // http://www.spauda.lt/history/lith/lt-protest.htm. Žiūrèta 2013-07-29.

51 Ten pat.

52 Brangūs skaitytojai // Srovè. 193112 25. Nr. 1. P. 1.

53 Lug und Trug ist der Welt Acker und Pflug (Melas ir apgavystè yra pasaulio dirva ir arklas) // Srovè. 193112 15. Nr. 1. P. 4.

54 Kaip „D. Nachrichten“ šalina politiką iš bažnyčios // Srovè. 19311215 . Nr. 1. P. 4.

55 Tiesmyla. Mūsų kelias // Srovè. 193201 25. Nr. 2. P. 1.

56 Slavenienè. Evangelikai liuteronai. Ten pat.

57 Agento „Informatorius“ agentūrinis pranešimas 19340319 // LCVA. F. 378. Ap. 5. B. 2439. L. 21.

58 Puidokienè I. Kauno evangelikų liuteronų bažnyčios vidaus konfliktas 1918-1940 m. // Kauno istorijos metraštis. Kaunas: Vytauto Didžiojo universiteto leidykla. 2009. T. 10. P. 65.

59 Lietuvos evangelikų liuteronų konsistorijos pranešimas Švietimo ministerijai 19350406 // LCVA. F. 391. Ap. 4. B. 631. L. 110.

60 Valstybès saugumo policijos Kauno apygardos 1934 m. spalio mèn. apžvalga // LCVA. F. 378 . Ap. 3. B. 3475. L. 129.

61 Kaune lietuviai evangelikai liuteronai negalejo išlikti ramūs. Po 1935 m. pradžioje Kaune ịvykusių vietos evangelikų liuteronų Kauno tarybos vokiškosios dalies rinkimų (tarybos pirmininku numatytas vokiškosios dalies atstovas, Kulturverbando narys H. Domela) pageidauta, kad Kauno parapijos tarybos vokiškoji dalis veiktų visai atskirai, t. y. kad būtų ịsteigta atskira evangelikų liuteronų vokiškoji Kauno parapija. Pastarasis pasiūlymas buvo pateiktas pastoriaus Tittelbacho, kuris minètiems rinkimams ir vadovavo. (Valstybès saugumo policijos Kauno apygardos $1936 \mathrm{~m}$. sausio mèn. apžvalga // LCVA. F. 378. Ap. 3. B. 4632. L. 233).

62 Išsamiau apie nesutarimus tarp lietuvių ir vokiečių evangelikų liuteronų Kaune žr. Puidokiené I. Kauno evangelikų liuteronų bažnyčios vidaus konfliktas 1918-1940 m. // Kauno istorijos metraštis. Kaunas: Vytauto Didžiojo universiteto leidykla. 2009. T. 10. P. 59-72; Puidokiené J. Kauno evangelikų liuteronų parapija 1919-1953 m. // SOTER. Kaunas: Vytauto Didžiojo universiteto leidykla. 2013. Nr. 46 (74). P. 69-82.

63 Valstybès saugumo ir kriminalinès policijos Marijampolès apygardos $1934 \mathrm{~m}$. rugsèjo mèn. žinių santrauka // LCVA. F. 378. Ap. 3. B. 3475. L. 218.

\section{LITERATŪRA IR ŠALTINIAI}

\section{Archyviniai fondai}

Lietuvos centrinis valstybès archyvas (LCVA). F. 377, 378, 391, 394, 1778.

\section{Publikuoti šaltiniai ir literatūra}

1. Brangūs skaitytojai // Srovè. 193112 25. Nr. 1. P. 1. 
2. Hermann A. Lietuvių ir vokiečių kaimynystè. Vilnius: Baltos lankos. 2000.

3. Hermann A. Lietuvos evangelikų liuteronų bažnyčia 1915-1995 m. // Lietuvos evangelikų bažnyčios: istorijos metmenys (sud. A. Hermann). Vilnius: Baltos lankos. 1993. P. 221-276.

4. Jakubavičienè I. Moterų vaidmuo Lietuvos vokiečių organizacijų veikloje XX a. 3-4 dešimtmečiuose // Lyčių studijos ir tyrimai. Šiauliai: Šiaulių universiteto leidykla. 2009. Nr. 7.

5. Kaip „D. Nachrichten“ šalina politiką iš bažnyčios // Srovè. 193112 15. Nr. 1. P. 4.

6. Lietuva. Lietuvių enciklopedija. Vilnius: Lietuvos enciklopedijų redakcija. 1990. T. 15. P. 177.

7. Lietuvos gyventojų konfesinè sudètis $1923 \mathrm{~m}$. rugsèjo $17 \mathrm{~d}$. gyventojų surašymo duomenimis // http://gevask.dtiltas.lt/LS1919/HTM/a057.html. Žiūrèta 2013-07-18.

8. Lietuvos gyventojų konfesinè sudètis tautybėmis $1923 \mathrm{~m}$. rugsèjo 17 d. gyventojų surašymo duomenimis \% // http://gevask.dtiltas.lt/LS1919/HTM/a058.html. Žiūrèta 2013-07-18.

9. Lug und Trug ist der Welt Acker und Pflug (Melas ir apgavystė yra pasaulio dirva ir arklas) // Srovè. 193112 15. Nr. 1. P. 4.

10. Puidokienè I. Die deutsche Minderheit in Litauen 1918-1940 (ohne das Memelgebiet) // Annaberger Annalen. 19/2011. S. 29-67.

11. Puidokienè I. Kauno evangelikų liuteronų bažnyčios vidaus konfliktas 1918-1940 m. // Kauno istorijos metraštis. Kaunas: Vytauto Didžiojo universiteto leidykla. 2009. T. 10. P. 59-72.

12. Puidokienè J. Kauno evangelikų liuteronų parapija 1919-1953 m. // SOTER. Kaunas: Vytauto Didžiojo universiteto leidykla. 2013. Nr. 46 (74). P. 69-82.

13. Puidokienè I. Vokiečių tautinè mažuma Lietuvos Respublikoje 1918-1940 m. (Be Klaipèdos krašto). Magistro baigiamasis darbas. Kaunas: Vytauto Didžiojo universiteto leidykla. 2009. vddb.library. lt/fedora/get/LT-eLABa-0001:E.02 2009 D_20090813_093356-58392/DS.005.0.02.ETD. Žiūrèta 2013-06-20.

14. Slavenienè G. Evangelikai liuteronai. http://www.spauda.lt/history/lith/lt-protest.htm. Žiūrèta 2013-07-29.

15. Slavenienè M. G. Evangelikų teologijos fakultetas Kaune 1925-1936 m. // Lietuvos evangelikų bažnyčios. Istorijos metmenys (sud. A. Hermann). Vilnius: Baltos lankos. 1993. P. 399-416.

16. Tautybių konfesinè sudètis $1923 \mathrm{~m}$. rugsèjo 17 d. gyventojų surašymo duomenimis \% // http:// gevask.dtiltas.lt/LS1919/HTM/a059.html. Žiūrèta 2013-07-18.

17. Tiesmyla. Mūsų kelias // Srovè. 193201 25. Nr. 2. P. 1.

Gauta: 20130927

Parengta spaudai: 20140221

\title{
Mindaugas TAMOŠAITIS
}

\section{RELATIONS BETWEEN LITHUANIAN GERMANS AND LITHUANIANS IN THE EVANGELICAL LUTHERAN CHURCH (1918-1940)}

\author{
S u $\mathrm{m} m$ a r y
}

The relations between Lithuanian Germans and Lithuanian Evangelical Lutherans have not been thoroughly covered in historiography. The studies of German historian Arthur Hermann, who among other things gives a general overview of the activities of the Consistory of Lithuanian Evangelical Lutherans and German Evangelical Lutherans, their relations with Lithuanian Evangelical Lutherans and other similar issues, make an exception. The activities of the Faculty of Evangelical Theology in Kaunas in 1925-1936, the interior conflict in the Kaunas Evangelical Lutheran Church in 1918-1940 and Kaunas Evangelical Lutheran Parish in general in 1919-1953 have also captured the attention of historians. Whereas the studies accomplished to this day do not provide a comprehensive view of the relations between Lithuanian Germans and Lithuanian Evangelical Lutherans during the analyzed period, a decision was made to bring this publication to life in the attempt to fill the existing gaps in historiography. 
The aim of the article is to reveal the relations between Lithuanian Germans and Lithuanian Evangelical Lutherans from 1918 to 1940.

Abundant archival data, which for the most part is kept in the Lithuanian State Central Archives (LSCA), helped to reveal the topic under discussion. The data stored at the fund of the State Security Department (f. 378) of the said archives (monthly reviews and reports prepared by the political police) on the activities of Germans residing in Lithuania is especially valuable. The documents kept at the fund of the Ministry of Interior (f. 377) and other funds of the archives, as well as periodical press of that time were also used.

According to the Lithuanian census of 1923, the religious distribution of local Germans (excluding those from Klaipeda Region), whose population at that time amounted to 29,231, was as follows: Roman Catholics 207, Jews - 1, Evangelical Lutherans - 28,671 (it accounted for as much as $98.08 \%$ of the total Lithuanian German population), Orthodox - 26, Evangelical Reformers - 212, Baptists - 48, Evangelical Methodists - 43, Free Evangelicals - 18, non-believers - 1, Adventists - 4. This census revealed that the counties of Taurage, Vilkaviškis, Šiauliai, Kaunas, Šakiai, Marijampolè, Biržai were the largest centres of Evangelical Reformers in Lithuania.

The research revealed that in the first decade of independence the domination of Germans in the Lithuanian Evangelical community was determined by the leading positions held for a long time by the representatives of this nationality in the Church of the Evangelical community of the country and the monopoly held by German Evangelical Lutheran priests in preaching the doctrine to believers (in the first years of independence the numbers of Lithuanian Evangelical Lutheran priests were very scarce), as well as a quantitative advantage of the German community (in 1923 Germans made up $43.06 \%$, Lithuanians - $33.51 \%$, Latvians - $20.36 \%$ of the overall Evangelical Lutheran community, while the remaining small part of Evangelical Lutherans consisted of other nationalities and foreigners). However, in 1930s Germans lost their leading positions in the Lithuanian Evangelical Lutheran community. It was due to the strict position of the leadership of the Consistory of Lithuanian Evangelicals in their fight against Germanization among Evangelical Lutherans, the growth of the number of Lithuanian Evangelical Lutheran priests and the growing awareness of Lithuanian Evangelical Lutherans themselves in the struggle with German Evangelical Lutherans for their equal rights and the leading role in the aforementioned religious community.

PAGRINDINIAI ŽODŽIAI: evangelikai liuteronai, vokiečiai, lietuviai, konsistorija, sinodas, kunigas, Bažnyčia, vokietinimas, Evangelikų teologijos fakultetas.

KEY WORDS: Evangelical Lutherans, Germans, Lithuanians, consistory, synod, priest, Church, Germanization, Faculty of Evangelical Theology.

Mindaugas TAMOŠAITIS - humanitarinių mokslų daktaras, Lietuvos edukologijos universiteto Lietuvos istorijos katedros docentas. Mokslinių interesų sritys: Lietuvos Respublikos (1918-1940 m.) politinė raida, moderniųjų laikų Lietuvos parlamentarizmo raida, tautinių mažumų istorija. Adresas: T. Ševčenkos g. 31, 03111 Vilnius. El. paštas mindaugas.tamosaitis@leu.lt.

Mindaugas TAMOŠAITIS - doctor of humanities, associate professor at the Department of Lithuanian History in Lithuanian University of Educational Sciences. Research interests: political development of the Republic of Lithuania (1918-1940), development of the Lithuanian parliamentary system of modern times, history of national minorities. Address: T. Ševčenkos g. 31, 03111 Vilnius. E-mail: mindaugas.tamosaitis@leu.lt. 